\title{
Description and evaluation of the Multiscale Online Nonhydrostatic AtmospheRe CHemistry model (NMMB-MONARCH) version 1.0: gas-phase chemistry at global scale
}

\author{
Alba Badia ${ }^{1, a}$, Oriol Jorba ${ }^{1}$, Apostolos Voulgarakis ${ }^{2}$, Donald Dabdub $^{3}$, Carlos Pérez García-Pando $^{4,5, b}$, \\ Andreas Hilboll $^{6,7}$, María Gonçalves ${ }^{1,8}$, and Zavisa Janjic ${ }^{9}$ \\ ${ }^{1}$ Earth Sciences Department, Barcelona Supercomputing Center, Barcelona, Spain \\ ${ }^{2}$ Department of Physics, Imperial College, London, UK \\ ${ }^{3}$ Mechanical and Aerospace Engineering, University of California, Irvine, USA \\ ${ }^{4}$ NASA Goddard Institute for Space Studies, New York, USA \\ ${ }^{5}$ Department of Applied Physics and Applied Math, Columbia University, New York, USA \\ ${ }^{6}$ Institute of Environmental Physics, University of Bremen, Bremen, Germany \\ ${ }^{7}$ MARUM - Center for Marine Environmental Sciences, University of Bremen, Bremen, Germany \\ ${ }^{8}$ Project and Construction Engineering Department, Universitat Politecnica de Catalunya, Barcelona, Spain \\ ${ }^{9}$ National Centers for Environmental Prediction, College Park, MD, USA \\ anow at: Centre for Ocean and Atmospheric Sciences, School of Environmental Sciences, \\ University of East Anglia, Norwich, UK \\ b now at: Earth Sciences Department, the Barcelona Supercomputing Center, Barcelona, Spain
}

Correspondence to: Oriol Jorba (oriol.jorba@bsc.es)

Received: 31 May 2016 - Discussion started: 13 June 2016

Revised: 13 January 2017 - Accepted: 17 January 2017 - Published: 10 February 2017

\begin{abstract}
This paper presents a comprehensive description and benchmark evaluation of the tropospheric gasphase chemistry component of the Multiscale Online Nonhydrostatic AtmospheRe CHemistry model (NMMBMONARCH), formerly known as NMMB/BSC-CTM, that can be run on both regional and global domains. Here, we provide an extensive evaluation of a global annual cycle simulation using a variety of background surface stations (EMEP, WDCGG and CASTNET), ozonesondes (WOUDC, CMD and SHADOZ), aircraft data (MOZAIC and several campaigns), and satellite observations (SCIAMACHY and MOPITT). We also include an extensive discussion of our results in comparison to other state-of-the-art models. We note that in this study, we omitted aerosol processes and some natural emissions (lightning and volcano emissions).

The model shows a realistic oxidative capacity across the globe. The seasonal cycle for CO is fairly well represented at different locations (correlations around 0.3-0.7 in surface concentrations), although concentrations are underestimated
\end{abstract}

in spring and winter in the Northern Hemisphere, and are overestimated throughout the year at 800 and $500 \mathrm{hPa}$ in the Southern Hemisphere.

Nitrogen species are well represented in almost all locations, particularly $\mathrm{NO}_{2}$ in Europe (root mean square error - RMSE - below $5 \mathrm{ppb}$ ). The modeled vertical distributions of $\mathrm{NO}_{x}$ and $\mathrm{HNO}_{3}$ are in excellent agreement with the observed values and the spatial and seasonal trends of tropospheric $\mathrm{NO}_{2}$ columns correspond well to observations from SCIAMACHY, capturing the highly polluted areas and the biomass burning cycle throughout the year. Over Asia, the model underestimates $\mathrm{NO}_{x}$ from March to August, probably due to an underestimation of $\mathrm{NO}_{x}$ emissions in the region. Overall, the comparison of the modeled $\mathrm{CO}$ and $\mathrm{NO}_{2}$ with MOPITT and SCIAMACHY observations emphasizes the need for more accurate emission rates from anthropogenic and biomass burning sources (i.e., specification of temporal variability). 
The resulting ozone $\left(\mathrm{O}_{3}\right)$ burden $(348 \mathrm{Tg})$ lies within the range of other state-of-the-art global atmospheric chemistry models. The model generally captures the spatial and seasonal trends of background surface $\mathrm{O}_{3}$ and its vertical distribution. However, the model tends to overestimate $\mathrm{O}_{3}$ throughout the troposphere in several stations. This may be attributed to an overestimation of $\mathrm{CO}$ concentration over the Southern Hemisphere leading to an excessive production of $\mathrm{O}_{3}$ or to the lack of specific chemistry (e.g., halogen chemistry, aerosol chemistry). Overall, $\mathrm{O}_{3}$ correlations range between 0.6 and 0.8 for daily mean values. The overall performance of the NMMB-MONARCH is comparable to that of other state-of-the-art global chemistry models.

\section{Introduction}

Tropospheric ozone $\left(\mathrm{O}_{3}\right)$ is a radiatively active gas interacting with solar and terrestrial radiation that is mainly produced during the photochemical oxidation of methane $\left(\mathrm{CH}_{4}\right)$, carbon monoxide $(\mathrm{CO})$ and non-methane volatile organic compounds (NMVOCs) in the presence of nitrogen oxides $\left(\mathrm{NO}_{x}\right)$ (Crutzen, 1974; Derwent et al., 1996). Downward transport from the stratosphere, where $\mathrm{O}_{3}$ is created by photolysis of oxygen $\left(\mathrm{O}_{2}\right)$ molecules, is also an important source of tropospheric $\mathrm{O}_{3}$ (Stohl et al., 2003; Hsu and Prather, 2009). In urban areas, $\mathrm{O}_{3}$ is a major component of "smog", which can cause a number of respiratory health effects (WHO, 2014). Since the pre-industrial era, changes in emissions of $\mathrm{O}_{3}$ precursors from anthropogenic and biomass burning sources have modified the distribution of tropospheric $\mathrm{O}_{3}$ and other trace gases (Lamarque et al., 2013). Tropospheric $\mathrm{O}_{3}$, with an average lifetime on the order of weeks, is highly variable in space and time, and air quality models (AQMs) are required to predict harmful levels of $\mathrm{O}_{3}$ along with its precursors and other trace gases.

AQMs are driven by meteorological fields and emissions of chemical species. They include a chemical mechanism for representing gas-phase and aerosol atmospheric chemistry, a photolysis scheme describing the photo-dissociation reactions driven by sunlight, dry and wet deposition schemes to account for the removal of pollutants from the atmosphere, and the characterization of the downward transport of stratospheric $\mathrm{O}_{3}$. The development of AQMs and meteorological models (MMs) evolved as separate fields (offline approach) due to complexity and limitations in computer resources. The offline approach requires lower computational capacity, but also involves a loss of essential information on atmospheric processes whose timescale is smaller than the output time rate of the meteorological model (Baklanov et al., 2014). Nowadays, owing to a general increase in computer capacity, online coupled meteorology-chemistry models are being increasingly developed and used by the scientific community, which recognizes the advantages of the online ap- proach (Byun, 1990). Overviews of online AQM-MM models are available in the literature (Zhang, 2008; Baklanov et al., 2014).

Several global AQMs have been developed during the last decades, including the multiscale GEM-AQ (online, $1.5^{\circ} \times$ $1.5^{\circ}$ ) (Gong et al., 2012), TM5-chem-v3.0 (offline, $3^{\circ} \times 2^{\circ}$ ) (Huijnen et al., 2010), LMDZ-INCA (offline, $3.8^{\circ} \times 2.5^{\circ}$ ) (Folberth et al., 2006), the GATOR-GCMM (online, $4^{\circ} \times 5^{\circ}$ ) (Jacobson, 2001), the IFS-MOZART used in the MACC project (online, $80 \mathrm{~km} \times 80 \mathrm{~km}$ ) (Flemming et al., 2009), CIFS recently developed at ECMWF (online, $80 \mathrm{~km} \times 80 \mathrm{~km}$ ) (Flemming et al., 2015), and MOZART-4 (offline, $2.8^{\circ} \times$ $2.8^{\circ}$ ) (Emmons et al., 2010). Most of these models have been applied at coarse resolutions with simplified chemical schemes. Currently, the systems are being updated and prepared for higher-resolution applications.

In this contribution, we describe the gas-phase chemistry of the Multiscale Online Nonhydrostatic AtmospheRe CHemistry model (NMMB-MONARCH), a chemical weather prediction system formerly known as NMMB/BSCCTM that can be run either globally or regionally (Pérez et al., 2011; Jorba et al., 2012). The NMMB-MONARCH, developed at the Barcelona Supercomputing Center, is based on the coupling of the meteorological Nonhydrostatic Multiscale Model on the B-grid (NMMB; Janjic and Gall, 2012) with a chemistry module. We provide a thorough evaluation of the gas-phase chemistry over a 1-year period for the global domain using a horizontal resolution of $1.4^{\circ} \times 1^{\circ}$.

The NMMB-MONARCH configured as a limited area (regional) model has recently participated in the Air Quality Model Evaluation International Initiative Phase2 (AQMEIIPhase2) intercomparison exercise (Im et al., 2014). Badia and Jorba (2014) also provided a detailed evaluation of the gas-phase chemistry for the year 2010 over Europe in the context of AQMEII-Phase2. The initial model developments focused on the implementation of the mineral dust aerosol component (NMMB/BSC-Dust; Pérez et al., 2011; Haustein et al., 2012) and the sea-salt aerosol component (Spada et al., 2013, 2015). The implementation and evaluation of other relevant aerosols will soon be described elsewhere (Spada et al., 2017). This initiative aims at developing a fully coupled chemical multiscale (global/regional) weather prediction system that resolves gas-aerosol-meteorology interactions and provides initial and boundary conditions for embedded high-resolution nests in a unified dynamics-physicschemistry environment.

The paper is organized as follows. In Sect. 2, we provide a description of the atmospheric driver, the gas-phase chemistry module, and the model configuration including the online biogenic emissions. Section 3 presents an overview of the model setup with a description of the chemical and meteorological initial conditions, and the anthropogenic and biomass burning emissions implemented for this experiment. We illustrate the capability of the NMMB-MONARCH to reproduce the atmospheric composition by evaluating the 
model with ground-based monitoring stations, ozonesondes, aircraft data, climatological vertical profiles and satellite retrievals, which are described in Sect. 4. The results of the model performance are discussed in Sect. 5 for the year 2004 . The last section summarizes the conclusions of this work.

\section{Model description}

The NMMB-MONARCH is a fully online multiscale chemical weather prediction system for regional and global-scale applications (Pérez et al., 2011; Jorba et al., 2012). The system is based on the meteorological Nonhydrostatic Multiscale Model on the B-grid (NMMB; Janjic and Gall, 2012), developed and widely verified at the National Centers for Environmental Prediction (NCEP). The model couples online the NMMB with the gas-phase and aerosol continuity equations to solve the atmospheric chemistry processes in detail. The model is designed to account for the feedbacks among gases, aerosol particles and meteorology. Currently, it can consider the direct radiative effect of aerosols while ignoring cloud-aerosol interactions. In this work, only the gas-phase chemistry is used; thus, no interaction between gas phase and aerosol phase is applied. In this section we provide a concise description of the NMMB and the gas-phase chemistry module of the NMMB-MONARCH.

\subsection{The Nonhydrostatic Multiscale Model on the B-grid}

The Nonhydrostatic Multiscale Model on the B-grid (NMMB; Janjic, 2005; Janjic and Gall, 2012) was conceived for short- and medium-range forecasting over a wide range of spatial and temporal scales, from large eddy simulations (LES) to global simulations. Its unified nonhydrostatic dynamical core allows for running of either regional or global simulations, both including embedded regional nests. The NMMB has been developed within the Earth System Modeling Framework (ESMF) at NCEP, following the general modeling philosophy of the NCEP regional Weather Research and Forecasting (WRF) Nonhydrostatic Mesoscale Model (NMM; Janjic et al., 2001; Janjic, 2003). The regional NMMB has been the operational regional North American Mesoscale (NAM) model at NCEP since October 2011. The numerical schemes used in the model were designed following the principles presented in Janjic (1977, 1979, 1984, 2003). Isotropic horizontal finite volume differencing is employed so that a variety of basic and derived dynamical and quadratic quantities are conserved. Among these, the conservation of energy and enstrophy (Arakawa, 1966) improves the accuracy of the non-linear dynamics. The hybrid pressure-sigma coordinate is used in the vertical direction and the Arakawa B-grid is applied in the horizontal direction. The global model on the latitude-longitude grid with polar filtering was developed as the reference version, and other geometries such as the cubed sphere are currently being tested. The regional model is formulated on a rotated longitude-latitude grid, with the Equator of the rotated system running through the middle of the integration domain, resulting in more uniform grid distances. The nonhydrostatic component of the model dynamics is introduced through an add-on module that can be turned on or off, depending on the resolution. The operational physical package includes (1) the Mellor-Yamada-Janjic (MYJ) level 2.5 turbulence closure for the treatment of turbulence in the planetary boundary layer (PBL) and in the free atmosphere (Janjic et al., 2001), (2) the surface layer scheme based on the Monin-Obukhov similarity theory (Monin and Obukhov, 1954) with an introduced viscous sublayer over land and water (Zilitinkevich, 1965; Janjic, 1994), (3) the NCEP NOAH (Ek et al., 2003) or the LISS land surface model (Vukovic et al., 2010) for the computation of the heat and moisture surface fluxes, (4) the GFDL or RRTMG longwave and shortwave radiation package (Fels and Schwarzkopf, 1975; Mlawer et al., 1997), (5) the Ferrier grid-scale clouds and microphysics (Ferrier et al., 2002), and (6) the Betts-Miller-Janjic convective parametrization (Betts, 1986; Betts and Miller, 1986; Janjic, 1994, 2000). Vertical diffusion is handled by the surface layer scheme and by the PBL scheme. Lateral diffusion is formulated following the Smagorinsky non-linear approach (Janjic, 1990). Table 1 describes the main configuration of the meteorological model used in this work.

\subsection{Gas-phase chemistry module}

The tropospheric gas-phase chemistry module is coupled online within the NMMB. Different chemical processes were implemented following a modular operator splitting approach to solve the advection, diffusion, chemistry, dry and wet deposition, and emission processes. Meteorological information is available at each time step to solve the chemical processes. In order to maintain consistency with the meteorological solver, the chemical species are advected and mixed at the corresponding time step of the meteorological tracers using the same numerical schemes implemented in the NMMB. The advection scheme is Eulerian, positive definite and monotone, maintaining a consistent mass conservation of the chemical species within the domain of study (Janjic et al., 2009; Tang et al., 2009; Janjic and Gall, 2012).

\subsubsection{Chemical-phase reaction mechanism}

Several chemical mechanisms can be implemented within the NMMB-MONARCH. A modular coupling with the Kinetic PreProcessor (KPP) package (Damian et al., 2002; Sandu and Sander, 2006) allows the model to maintain wide flexibility. Additionally, an Eulerian backward iterative solver (Hertel et al., 1993) was implemented as a complementary option to the KPP solvers to allow the model to run with a fast ordinary differential equation solver at global scales. For the 
Table 1. Model characteristics and experiment configuration.

\begin{tabular}{ll}
\hline Meteorology & \\
\hline Dynamics & Nonhydrostatic NMMB (Janjic and Gall, 2012) \\
Physics & Ferrier microphysics (Ferrier et al., 2002) \\
& BMJ cumulus scheme (Betts and Miller, 1986) \\
& MYJ PBL scheme (Janjic et al., 2001) \\
& LISS land surface model (Vukovic et al., 2010) \\
& RRTMG radiation (Mlawer et al., 1997) \\
\hline Chemistry & \\
\hline Chemical mechanism & Carbon Bond 2005 (Yarwood et al., 2005) \\
Photolysis scheme & Online Fast-J photolysis scheme (Wild et al., 2000) \\
Aerosols & No aerosols considered in this study \\
Dry deposition & Wesley resistance approach from Wesely (1989) \\
Wet deposition & Grid and sub-grid scale from Foley et al. (2010) \\
Biogenic emissions & MEGAN (Guenther et al., 2006) \\
Anthropogenic and other natural emissions & ACCMIP (Lamarque et al., 2010) and POET (Granier et al., 2005) \\
Stratospheric ozone & COPCAT (Monge-Sanz et al., 2011) \\
\hline Resolution and initial conditions & \\
\hline Horizontal resolution & $1.4^{\circ} \times 1^{\circ}$ \\
Vertical layers & 64 \\
Top of the atmosphere & 1 hPa \\
Chemical initial condition & MOZART4 (Emmons et al., 2010) \\
Meteorological initial condition & FNL/NCEP \\
Chemistry spin-up & 1 year \\
\hline
\end{tabular}

present study, we use a Carbon-Bond family mechanism, the Carbon Bond 2005 (CB05; Yarwood et al., 2005), an updated version of the Carbon Bond IV (CB4) lumped-structure-type mechanism (Gery et al., 1989). CB4 was formulated focusing on limited domain extent, urban and regional environments and for planetary boundary layer chemistry. CB05 extends its applicability from urban to remote tropospheric conditions and is suitable for global applications. CB05 was evaluated against smog chamber data from the University of California, Riverside, and the University of North Carolina (Yarwood et al., 2005). It includes 51 chemical species and solves 156 reactions (see Tables S1 and S2 in the Supplement). Both the organic chemistry of methane and ethane, and the chemistry of methylperoxy radical, methyl hydroperoxide and formic acid are treated explicitly. The higher organic peroxides, organic acids, and peracids are treated as lumped species. Following its main design, CB05 defines proxy single and double carbon bond species, paraffin and an olefin bond, respectively, and it introduces the internal olefin species. The rate constants were updated based on evaluations from Atkinson et al. (2004) and Sander et al. (2006). Organic compounds not explicitly treated are apportioned to the carbon-bond species based on the molecular structure and following Yarwood et al. (2005) assignments from VOC species to CB05 model species. The concentration of methane is considered constant (1.85 ppm) in this study.

\subsubsection{Photolysis scheme}

One of the most important processes determining tropospheric composition is the photo-dissociation of trace gases. Table S3 lists the photolysis reactions considered. To compute the photolysis rates, we implemented the Fast-J (Wild et al., 2000) online photolysis scheme. Fast-J has been coupled with the physics of each model layer (e.g., clouds and absorbers such as $\mathrm{O}_{3}$ ). The optical depths of grid-scale clouds from the atmospheric driver are considered by using the fractional cloudiness based on relative humidity (Fast et al., 2006). The main advantages of Fast-J are the optimization of the phase function expansion into Legendre polynomials and the optimization of the integration over wavelength (Wild et al., 2000). The Fast-J scheme has been upgraded with CB05 photolytic reactions. The quantum yields and cross section for the CB05 photolysis reactions have been revised and updated following the recommendations of Atkinson et al. (2004) and Sander et al. (2006). The Fast-J scheme uses seven different wavelength bins appropriate for the troposphere to calculate the actinic flux covering from 289 to $850 \mathrm{~nm}$ (see Table VIII from Wild et al., 2000). In this work, aerosols are not considered in the photolysis rate calculation. This might produce an atmosphere excessively oxidized in regions where aerosols are significant (e.g., Bian et al., 2003; Real and Sartelet, 2011). 


\subsubsection{Dry-deposition scheme}

The dry-deposition scheme is responsible for computing the flux of trace gases from the atmosphere to the surface. It is calculated by multiplying the concentration in the lowest model layer by the spatially and temporally varying deposition velocity:

${\frac{\partial C_{i}}{\partial t}}_{\text {dry-dep }}=-C_{i} v_{\mathrm{d}}$,

where $t$ is the time, $i$ is the gas-phase species, $C_{i}$ is the concentration of the gas in the lowest model layer, and $v_{\mathrm{d}}$ is the dry-deposition velocity. At each time step, $v_{\mathrm{d}}$ is calculated according to

$\left|v_{\mathrm{d}}\right|=\frac{1}{\left(R_{\mathrm{a}}+R_{\mathrm{b}}+R_{\mathrm{c}}\right)}$,

where $R_{\mathrm{a}}$ is the aerodynamic resistance (depends only on atmospheric conditions), $R_{\mathrm{b}}$ is the quasilaminar sublayer resistance (depends on friction velocity and molecular characteristics of gases), and $R_{\mathrm{c}}$ is the canopy or surface resistance (depends on surface properties and the reactivity of the gas). $R_{\mathrm{a}}$ and $R_{\mathrm{b}}$ are computed following their common definition (Seinfeld and Pandis, 1998), while $R_{\mathrm{c}}$ is simulated following Wesely (1989), where the surface resistance is derived from the resistances of the surfaces of the soil and the plants. The properties of the plants are determined using land-use data (from the USGS land use of the meteorological driver) and depend on the season. The surface resistance also depends on the diffusion coefficient, the reactivity, and the water solubility of the reactive trace gases.

\subsubsection{Wet-deposition scheme}

We use the scheme of Byun and Ching (1999) and Foley et al. (2010) to resolve the cloud processes affecting the concentration of 36 gases from the $\mathrm{CB} 05$ chemical mechanism. The processes included are grid-scale scavenging and wet deposition, subgrid-scale vertical mixing, scavenging and wet deposition for precipitating and non-precipitating clouds. Aqueous chemistry is neglected in version 1.0 of the model. At the moment, we consider only in-cloud scavenging, which is computed using the Henry's law equilibrium equation. The rate of change for in-cloud pollutant concentration is given by

$\frac{\partial C_{i_{\mathrm{cld}}}}{\partial t}=C_{i_{\mathrm{cld}}} \frac{e^{-\alpha_{i} \tau_{\mathrm{cld}}}-1}{\tau_{\mathrm{cld}}}$,

where $C_{i_{\mathrm{cld}}}$ is the gas concentration within the cloud (ppm), $\tau_{\text {cld }}$ is the cloud timescale (s), and $\alpha_{i}$ is the scavenging coefficient for the gas species that is calculated as

$\alpha_{i}=\frac{1}{\tau_{\text {washout }}\left(1+\frac{\mathrm{TWF}}{H_{i}}\right)}$, where $H_{i}$ is the Henry's law coefficient for the gas species $\left(\mathrm{M} \mathrm{atm}^{-1}\right), \mathrm{TWF}=\rho_{\mathrm{H}_{2} \mathrm{O}} /\left(W_{\mathrm{T}} R T\right)$ is the total water fraction (where $\rho_{\mathrm{H}_{2} \mathrm{O}}$ is the density of water $\left(\mathrm{kg} \mathrm{m}^{-3}\right), W_{\mathrm{T}}$ is the total mean water content $\left(\mathrm{kg} \mathrm{m}^{-3}\right), R$ is the universal gas constant, and $T$ is the in-cloud air temperature $(\mathrm{K}))$, and $\tau_{\text {washout }}$ is the washout time (s), i.e., the amount of time required to remove all of the water from the cloud volume at a specified precipitation rate, which is given by

$\tau_{\text {washout }}=\frac{W_{\mathrm{T}} \Delta Z_{\mathrm{cld}}}{\rho_{\mathrm{H}_{2} \mathrm{O}} P_{\mathrm{r}}}$,

where $\Delta Z_{\text {cld }}$ is the cloud thickness $(\mathrm{m})$ and $P_{\mathrm{r}}$ is the precipitation rate $\left(\mathrm{m} \mathrm{s}^{-1}\right)$. Both grid-scale and subgrid-scale scavenging are computed with Eq. (3), where $\tau_{\text {cld }}$ is $1 \mathrm{~h}$ for subgrid-scale clouds, and the chemistry time step for gridscale clouds. Wet deposition is computed following the algorithm of Chang et al. (1987), which depends upon $P_{\mathrm{r}}$ and the gas concentration within the cloud $C_{i_{\mathrm{cld}}}$. Thus, the wet deposition is given by

$\mathrm{wdep}_{i}=\int_{0}^{\tau_{\mathrm{cld}}} C_{i_{\mathrm{cld}}} P_{\mathrm{r}} \mathrm{d} t$.

The sub-grid cloud scheme implemented solves convective mixing, scavenging and wet deposition of a representative cloud within the grid cell following the CMAQ and RADMv2.6 model schemes (Byun and Ching, 1999; Chang et al., 1987). Precipitating and non-precipitating sub-grid clouds are considered. The latter are categorized as pure fair weather clouds and non-precipitating clouds and may coexist with precipitating clouds (Byun and Ching, 1999; Foley et al., 2010).

\subsubsection{Upper boundary conditions}

Because the model focuses on the troposphere, stratospheric chemistry is taken into account using a simplified approach. Above $100 \mathrm{hPa}$, mixing ratios of several species (NO, $\mathrm{NO}_{2}$, $\mathrm{N}_{2} \mathrm{O}_{5}, \mathrm{HNO}_{3}$ and $\mathrm{CO}$ ) are initialized each day from a global chemical model, MOZART-4 (Emmons et al., 2010). For O $\mathrm{O}_{3}$, an important reactive gas requiring a more refined representation in the stratosphere, we use a linear $\mathrm{O}_{3}$ stratospheric scheme, COPCAT (Monge-Sanz et al., 2011). COPCAT is based on the approach of Cariolle and Déqué (1986), which represented the first effort to include a linearized $\mathrm{O}_{3}$ scheme (named Cariolle v1.0) in a three-dimensional model.

In COPCAT the linear coefficients are obtained at equilibrium from the TOMCAT/SLIMCAT box model (Chipperfield, 2006). These terms are presented as functions of 24 latitudes, 24 model vertical levels and 12 months.

Heterogeneous processes describing the polar stratospheric chemistry are non-linear and depend on the threedimensional structure of the atmosphere. COPCAT includes complete heterogeneous processes in their coefficients, con- 
Table 2. Emission totals by category in $\operatorname{Tg}$ (species) year $^{-1}$ for 2004. Anthropogenic and biomass burning emissions applied in this study are based on Lamarque et al. (2013). Ocean and soil natural emissions are based on the POET global inventory (Granier et al., 2005). Biogenic emissions are computed online from MEGAN (Guenther et al., 2006).

\begin{tabular}{lrrrrr}
\hline Species & Anthrop. & Bio. burning & Biogenic & Soil & Ocean \\
\hline $\mathrm{CO}$ & 610.5 & 459.6 & 148.13 & - & 19.85 \\
$\mathrm{NO}$ & 85.8 & 5.4 & 16.54 & 11.7 & - \\
$\mathrm{SO}_{2}$ & 92.96 & 3.84 & - & - & - \\
Isoprene $\left(\mathrm{C}_{5} \mathrm{H}_{8}\right)$ & - & 0.15 & 683.16 & - & - \\
Terpene $\left(\mathrm{C}_{10} \mathrm{H}_{6}\right)$ & - & 0.03 & 120.85 & - & - \\
Xylenes $\left(\mathrm{C}_{8} \mathrm{H}_{10}\right)$ & 1.05 & 0.16 & 1.36 & - & - \\
Methanol $\left(\mathrm{CH}_{3} \mathrm{OH}\right)$ & - & - & 159.91 & - & - \\
Ethanol $\left(\mathrm{C}_{2} \mathrm{H}_{6} \mathrm{O}\right)$ & 4.28 & 3.7 & 17.06 & - & - \\
Formaldehyde $(\mathrm{HCHO})$ & 4.24 & 0.35 & 9.58 & - & - \\
Aldehyde $(\mathrm{R}-\mathrm{CHO})$ & - & - & 5.06 & - & - \\
Toluene $\left(\mathrm{C}_{7} \mathrm{H}_{8}\right)$ & 0.66 & 0.19 & 0.79 & - & - \\
Ethane $\left(\mathrm{C}_{2} \mathrm{H}_{6}\right)$ & 1.27 & 0.57 & 0.48 & - & - \\
Ethylene $\left(\mathrm{C}_{2} \mathrm{H}_{4}\right)$ & 3.32 & 2.71 & 32.03 & - & - \\
\hline
\end{tabular}

sidering heterogeneous and gas-phase chemistry to be consistent when applied in this linear $\mathrm{O}_{3}$ parameterization. This kind of parameterization is in better agreement with the current state of knowledge of stratospheric heterogeneous chemistry than previous schemes (Monge-Sanz et al., 2011). For further description of the approach and information on the biases of the stratosphere ozone simulated by the COPCAT scheme, the reader is referred to Monge-Sanz et al. (2011).

\subsubsection{Online natural emissions}

Natural emissions of gaseous pollutants include biogenic emissions, soil emissions, emissions from lightning, and emissions from oceans and volcanoes. Currently, soil and oceanic emissions in the model are prescribed as described in Sect. 3.1 and emissions from lightning and volcanoes are not considered. The omission of lightning emissions may have a significant impact on the oxidation of the middle and upper troposphere. Only biogenic emissions, which strongly depend on meteorological fields and vegetation cover, are calculated online. They are computed using the Model of Emissions of Gases and Aerosols from Nature version 2.04 (MEGANv2; Guenther et al., 2006). MEGAN is able to estimate the net emission rate of gases and aerosols from terrestrial ecosystems into the above-canopy atmosphere. MEGAN canopy-scale emission factors differ from most other biogenic emission models, which use leaf-scale emission factors and cover more than 130 non-methane volatile organic compounds (NMVOCs). All the MEGAN NMVOCs are speciated following the CB05 chemical mechanism; thus, emissions for isoprene, lumped terpenes, methanol, nitrogen monoxide, acetaldehyde, ethanol, formaldehyde, higher aldehydes, toluene, carbon monoxide, ethane, ethene, paraffin carbon bond, and olefin carbon bond are considered within the model. Biogenic emissions are computed every hour to account for evolving meteorological changes in solar radiation and surface temperature. Thus, the weather-driving variables considered are temperature at $2 \mathrm{~m}$ and incoming shortwave radiation at the surface.

Figure S1 in the Supplement shows the modeled emission for isoprene and terpenes for January and July 2004, and Table 2 lists the global annual emissions for isoprene, monoterpenes and other important NMVOCs. Biogenic isoprene emissions used in this study amount to $683.16 \mathrm{Tg}_{\mathrm{gear}}{ }^{-1}$. While other global models have lower estimates (Huijnen et al., 2010; Horowitz et al., 2003; Emmons et al., 2010), MEGAN isoprene emissions typically range from about 500 to $750 \mathrm{Tg}_{\text {year }}{ }^{-1}$ (Guenther et al., 2006). These estimates largely depend on the assumed land cover, emission factors, and meteorological parameters. Therefore, the emission uncertainties and their impacts upon surface $\mathrm{O}_{3}$ are associated with uncertainties in these inputs. Ashworth et al. (2010) obtained emission reductions of 3 and $7 \%$ when using daily and monthly meteorological data, respectively, instead of hourly data, with reductions reaching up to $55 \%$ in some locations. Marais et al. (2014) performed several sensitivity model runs to study the impact of different model input and settings on isoprene estimates that resulted in differences of up to $\pm 17 \%$ compared to a baseline. In our study, weather inputs are based on previous day $24 \mathrm{~h}$ averages and data of the hour of interest.

\section{Model setup}

The model is set up as global with a horizontal grid spacing of $1.4^{\circ} \times 1^{\circ}$ and 64 vertical layers up to $1 \mathrm{hPa}$. The depth of the bottom layer is below $40 \mathrm{~m}$. The dynamics fundamental time step is set to $180 \mathrm{~s}$ and the chemistry processes are solved every $720 \mathrm{~s}$. The radiation, photolysis scheme 

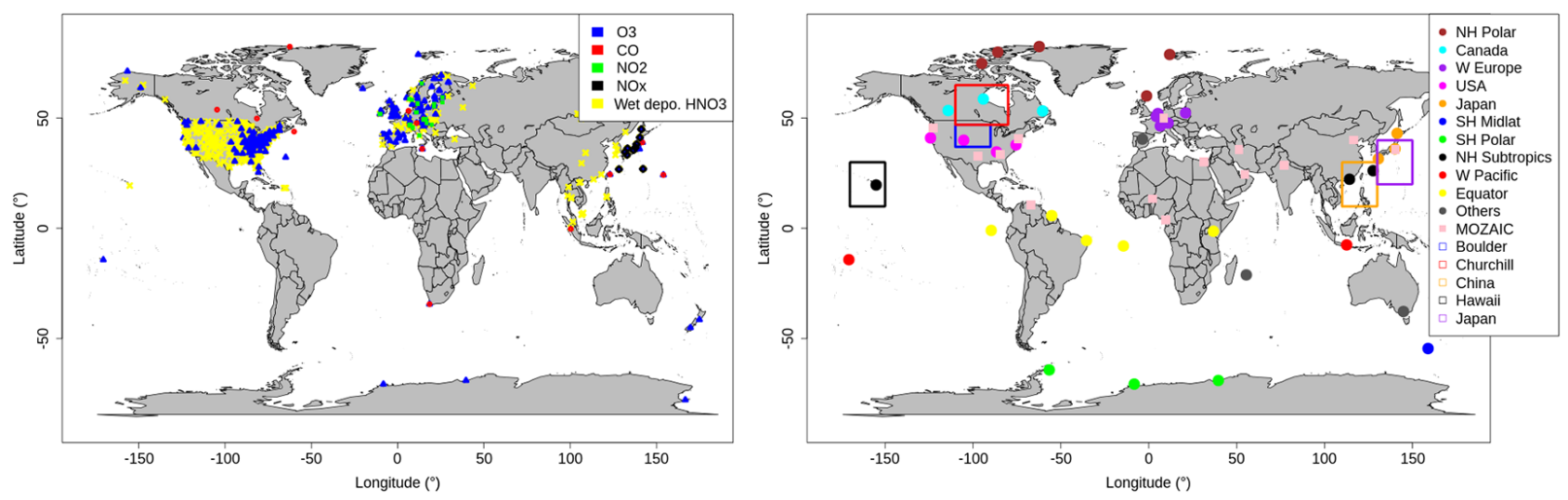

Figure 1. Stations used for the evaluation of the NMMB-MONARCH model. On the left, surface-monitoring rural stations of $\mathrm{O}_{3}$ (blue triangle), $\mathrm{CO}$ (red circle), $\mathrm{NO}_{2}$ (green square cross) and $\mathrm{NO}_{x}$ (black diamond) are shown. Moreover, wet deposition of $\mathrm{HNO}_{3}$ measurement locations (yellow cross) is presented. On the right, locations of the ozonesondes used are shown. Ozonesondes are grouped by the following regions: NH Polar (brown circle), Canada (cyan circle), W Europe (purple circle), US (pink circle), Japan (orange circle), SH Midlat (blue circle), SH Polar (green circle), NH Subtropics (black circle), W Pacific (red circle), Equator (yellow circle) and Others (gray circle). In addition, $\mathrm{CO}$ vertical profiles from the MOZAIC aircraft campaign (pink square) are presented. Finally, large rectangles show areas for the climatology analysis $\left(\mathrm{NO}_{x}, \mathrm{PAN}\right.$ and $\mathrm{HNO}_{3}$ ) for Boulder (blue), Churchill (red), China (orange), Hawaii (black) and Japan (purple).

and biogenic emissions are computed every hour. We use NCEP/Final Analysis (FNL) as initial conditions for the meteorological driver, and we reinitialize the meteorology every $24 \mathrm{~h}$ to reproduce the observed transport. We performed a spin-up of 1 year using initial chemistry conditions from the MOZART-4 global atmospheric model (Emmons et al., 2010) prior to the 2004 annual cycle simulation that is evaluated in the present study. Table 1 describes the main configuration of the model. The feedback between chemistry and meteorology is not considered in this study.

\subsection{Emissions}

The global emissions used in this study are based on the Atmospheric Chemistry and Climate Model Intercomparison Project (ACCMIP; Lamarque et al., 2013), which includes emissions from anthropogenic and biomass burning sources at $0.5^{\circ} \times 0.5^{\circ}$ horizontal resolution (Lamarque et al., 2010). Note that this methodology involves assuming 2004 emissions equivalent to the best estimate reported for the ACCMIP for the year 2000. Therefore specific events that occurred during 2004 (e.g., large summer wildfires in Alaska and Canada) are not described. The ACCMIP inventory is a combination of several existing regional and global inventories. The surface anthropogenic emissions are based on two historical emission inventories, namely RETRO (1960-2000; Schultz and Rast, 2007) and EDGAR-HYDE (1890-1990; Van Aardenne et al., 2005), and monthly variations for biomass burning and ship and aircraft emissions are provided. One limitation is that landbased anthropogenic emissions have constant values for the entire year. Lamarque et al. (2010) present a comparison of the annual total $\mathrm{CO}$ anthropogenic and biomass burning emissions $\left(\mathrm{Tg}(\mathrm{CO})\right.$ year $\left.^{-1}\right)$ for different regional and global emission inventories for the year 2000 (see Table 5 of this paper). Note that ACCMIP global CO anthropogenic emissions are significantly higher $\left(610.5 \mathrm{Tg} \mathrm{CO} \mathrm{year}^{-1}\right)$ than other emissions inventories (e.g., RETRO with $476 \mathrm{Tg} \mathrm{CO}_{\mathrm{year}}{ }^{-1}$, EDGAR-HYDE with $548 \mathrm{Tg} \mathrm{CO}_{\text {year }}{ }^{-1}$, and GAINS with $542 \mathrm{Tg} \mathrm{CO}$ year $^{-1}$ ).

Ocean and soil natural emissions are based on the POET (Granier et al., 2005) global inventory. Lightning and volcano emissions are not considered in this simulation. Biogenic emissions are computed using the MEGANv2.04 model as described in Sect. 2.2.6. NO emissions for January and July 2004 are shown in Fig. S1 and yearly totals for anthropogenic, biomass burning, biogenic, soil, and ocean emissions are summarized in Table 2.

To account for the sub-grid-scale vertical diffusion within the PBL, all the land-based anthropogenic emissions are emitted in the first $500 \mathrm{~m}$ of the model, biomass burning emissions from forests in the first $1300 \mathrm{~m}$, biomass burning emissions from grass in the first $200 \mathrm{~m}$, ocean emissions in the first $30 \mathrm{~m}$ and shipping emissions in the first $500 \mathrm{~m}$. This vertical distribution of emissions has been derived after some sensitivity runs and it may not be appropriate for higherresolution runs. The model does not include the attenuation of radiation due to aerosols in the photolysis scheme. Therefore, regions with strong biomass burning emissions may significantly overestimate chemical photolysis production (e.g., Bian et al., 2003; Real and Sartelet, 2011). 
Table 3. Main information about the ozonesondes used in this study, including the location and number of available measurements for each season (DJF for December-January-February, MAM for March-April-May, JJA for June-July-August and SON for September-OctoberNovember).

\begin{tabular}{|c|c|c|c|c|c|c|c|c|}
\hline Station & Country & Latitude & Longitude & Region & DJF & MAM & JJA & SON \\
\hline Kagoshima & Japan & $31.6^{\circ} \mathrm{N}$ & $130.6^{\circ} \mathrm{E}$ & Japan & 13 & 12 & 11 & 12 \\
\hline Saporo & Japan & $43.1^{\circ} \mathrm{N}$ & $141.3^{\circ} \mathrm{E}$ & Japan & 12 & 10 & 12 & 10 \\
\hline Tsukubay & Japan & $36.1^{\circ} \mathrm{N}$ & $140.1^{\circ} \mathrm{E}$ & Japan & 14 & 13 & 12 & 12 \\
\hline Alert & Canada & $82.5^{\circ} \mathrm{N}$ & $62.3^{\circ} \mathrm{W}$ & NH Polar & 11 & 10 & 13 & 9 \\
\hline Edmonton & Canada & $53.5^{\circ} \mathrm{N}$ & $114.1^{\circ} \mathrm{W}$ & Canada & 7 & 12 & 10 & 10 \\
\hline Resolute & Canada & $74.8^{\circ} \mathrm{N}$ & $95.0^{\circ} \mathrm{W}$ & NH Polar & 9 & 10 & 8 & 6 \\
\hline Macquarie Island & Australia & $54.5^{\circ} \mathrm{S}$ & $158.9^{\circ} \mathrm{E}$ & SH Midlat & 6 & 15 & 12 & 9 \\
\hline Lerwick & Great Britain & $60.1^{\circ} \mathrm{N}$ & $1.2^{\circ} \mathrm{W}$ & W Europe & 9 & 13 & 13 & 12 \\
\hline Uccle & Belgium & $50.8^{\circ} \mathrm{N}$ & $4.3^{\circ} \mathrm{E}$ & W Europe & 35 & 37 & 36 & 36 \\
\hline Goose Bay & Canada & $53.3^{\circ} \mathrm{N}$ & $60.4^{\circ} \mathrm{W}$ & Canada & 12 & 13 & 13 & 12 \\
\hline Churchill & Canada & $58.7^{\circ} \mathrm{N}$ & $94.1^{\circ} \mathrm{W}$ & Canada & 7 & 6 & 4 & 8 \\
\hline NyAlesund & Norway & $78.9^{\circ} \mathrm{N}$ & $11.9^{\circ} \mathrm{E}$ & NH Polar & 25 & 24 & 23 & 17 \\
\hline Hohenpeissenberg & Germany & $47.8^{\circ} \mathrm{N}$ & $11.0^{\circ} \mathrm{E}$ & Europe & 34 & 34 & 26 & 31 \\
\hline Syowa & Japan (Antarctica) & $69.0^{\circ} \mathrm{S}$ & $39.6^{\circ} \mathrm{E}$ & SH Polar & 16 & 16 & 19 & 26 \\
\hline Wallops Island & US & $37.9^{\circ} \mathrm{N}$ & $75.5^{\circ} \mathrm{W}$ & US & 11 & 15 & 17 & 7 \\
\hline Hilo & US & $19.7^{\circ} \mathrm{N}$ & $155.1^{\circ} \mathrm{W}$ & NH Subtropics & 13 & 18 & 14 & 12 \\
\hline Payerne & Switzerland & $46.5^{\circ} \mathrm{N}$ & $6.6^{\circ} \mathrm{E}$ & Europe & 38 & 40 & 38 & 40 \\
\hline Nairobi & Kenya & $1.3^{\circ} \mathrm{S}$ & $36.8^{\circ} \mathrm{E}$ & Equator & 11 & 13 & 13 & 13 \\
\hline Naha & Japan & $26.17^{\circ} \mathrm{N}$ & $127.7^{\circ} \mathrm{E}$ & NH Subtropics & 9 & 12 & 8 & 10 \\
\hline Samoa & Independent State of Samoa & $14.2^{\circ} \mathrm{S}$ & $170.6^{\circ} \mathrm{W}$ & W Pacific & 9 & 11 & 8 & 9 \\
\hline Legionowo & Poland & $52.4^{\circ} \mathrm{N}$ & $20.9^{\circ} \mathrm{E}$ & Europe & 16 & 18 & 16 & 18 \\
\hline Marambio & Antarctica & $64.2^{\circ} \mathrm{S}$ & $56.6^{\circ} \mathrm{W}$ & SH Polar & 10 & 7 & 15 & 22 \\
\hline Lauder & New Zealand & $45.0^{\circ} \mathrm{S}$ & $169.7^{\circ} \mathrm{E}$ & SH Midlat & 11 & 13 & 13 & 9 \\
\hline Madrid & Spain & $40.5^{\circ} \mathrm{N}$ & $3.6^{\circ} \mathrm{W}$ & Others & 11 & 9 & 8 & 12 \\
\hline Eureka & Canada & $80.0^{\circ} \mathrm{N}$ & $85.9^{\circ} \mathrm{W}$ & NH Polar & 17 & 17 & 11 & 13 \\
\hline De Bilt & Netherlands & $52.1^{\circ} \mathrm{N}$ & $5.2^{\circ} \mathrm{E}$ & Europe & 13 & 10 & 14 & 12 \\
\hline Neumayer & Antarctica & $70.7^{\circ} \mathrm{S}$ & $8.3^{\circ} \mathrm{W}$ & SH Polar & 11 & 13 & 13 & 31 \\
\hline Hong Kong & China & $22.3^{\circ} \mathrm{N}$ & $114.2^{\circ} \mathrm{E}$ & NH Subtropics & 12 & 26 & 11 & 13 \\
\hline Broad Meadows & Australia & $37.7^{\circ} \mathrm{S}$ & $144.9^{\circ} \mathrm{E}$ & Others & 6 & 7 & 7 & 11 \\
\hline Huntsville & US & $34.7^{\circ} \mathrm{N}$ & $86.6^{\circ} \mathrm{W}$ & US & 14 & 13 & 23 & 13 \\
\hline Parambio & Suriname & $5.8^{\circ} \mathrm{N}$ & $55.2^{\circ} \mathrm{W}$ & Equator & 11 & 8 & 9 & 9 \\
\hline Reunion Island & France & $21.1^{\circ} \mathrm{S}$ & $55.5^{\circ} \mathrm{E}$ & Others & 9 & 14 & 9 & 6 \\
\hline Watukosek & Indonesia & $7.5^{\circ} \mathrm{S}$ & $112.6^{\circ} \mathrm{E}$ & W Pacific & 7 & 11 & 10 & 6 \\
\hline Natal & Brazil & $5.5^{\circ} \mathrm{S}$ & $35.41^{\circ} \mathrm{W}$ & Equator & 10 & 12 & 13 & 7 \\
\hline Ascension Island & Great Britain & $7.98^{\circ} \mathrm{S}$ & $14.42^{\circ} \mathrm{W}$ & Equator & 12 & 12 & 12 & 18 \\
\hline San Cristobal & Galapagos & $0.92^{\circ} \mathrm{S}$ & $89.6^{\circ} \mathrm{W}$ & Equator & 7 & 4 & 10 & 13 \\
\hline Boulder & US & $40.0^{\circ} \mathrm{N}$ & $105.26^{\circ} \mathrm{W}$ & US & 12 & 11 & 17 & 16 \\
\hline Trinidad Head & US & $40.8^{\circ} \mathrm{N}$ & $124.2^{\circ} \mathrm{W}$ & US & 4 & 7 & 5 & 8 \\
\hline Suva & Fiji & $18.13^{\circ} \mathrm{S}$ & $178.4^{\circ} \mathrm{E}$ & W Pacific & 13 & 12 & 48 & 11 \\
\hline
\end{tabular}

\section{Observational data}

\subsection{Surface concentration and wet deposition}

For the evaluation of ground-level gas concentrations, we selected background stations having hourly data (Fig. 1, left panel) from the World Data Center for Greenhouse Gases (WDCGG; http://ds.data.jma.go.jp/gmd/wdcgg/), the European Monitoring and Evaluation Programme (EMEP; http: //www.emep.int/), the Clean Air Status and Trends Network in the United States (US) (CASTNET; http://java.epa.gov/ castnet/) and the Acid Deposition Monitoring Network in
East Asia (EANET; http://www.eanet.asia/). For $\mathrm{O}_{3}$, we used data from 41 WDCGG, 52 EMEP, 64 CASTNET and 11 EANET stations, covering Europe, the US, and a few locations in eastern Asia. We also selected 21 EMEP stations for $\mathrm{NO}_{2}, 10$ EANET stations for $\mathrm{NO}_{x}$ and 14 WDCGG stations for $\mathrm{CO}$.

The simulated wet deposition of $\mathrm{HNO}_{3}$ is also compared against observed nitrate $\left(\mathrm{HNO}_{3}\right.$ and aerosol nitrate) wet deposition, including 260 measurements from the National Atmospheric Deposition Program (NADP; http://nadp.sws. 
Table 4. MOZAIC aircraft information, including the location of measurements and the number of available measurements for each season (DJF, MAM, JJA and SON).

\begin{tabular}{llrr|rrrr}
\hline Station & Country & Latitude & Longitude & DJF & MAM & JJA & SON \\
\hline Abu Dhabi & United Arab Emirates & $24.44^{\circ} \mathrm{N}$ & $54.65^{\circ} \mathrm{E}$ & 11 & 17 & 58 & 20 \\
Atlanta & US & $33.63^{\circ} \mathrm{N}$ & $84.44^{\circ} \mathrm{W}$ & 24 & 130 & 168 & 66 \\
Beijing & China & $40.09^{\circ} \mathrm{N}$ & $116.6^{\circ} \mathrm{E}$ & 5 & 12 & 23 & 17 \\
Cairo & Egypt & $30.11^{\circ} \mathrm{N}$ & $31.41^{\circ} \mathrm{E}$ & 19 & 16 & 2 & 8 \\
Caracas & Venezuela & $10.6^{\circ} \mathrm{N}$ & $67^{\circ} \mathrm{W}$ & 21 & 9 & 9 & 21 \\
Dallas & US & $32.9^{\circ} \mathrm{N}$ & $97.03^{\circ} \mathrm{W}$ & 8 & 24 & 24 & 10 \\
Douala & Cameroon & $4.01^{\circ} \mathrm{N}$ & $9.72^{\circ} \mathrm{E}$ & 7 & 0 & 10 & 6 \\
Frankfurt & Germany & $50.02^{\circ} \mathrm{N}$ & $8.53^{\circ} \mathrm{E}$ & 169 & 295 & 286 & 192 \\
New Delhi & India & $28.56^{\circ} \mathrm{N}$ & $77.1^{\circ} \mathrm{E}$ & 30 & 24 & 72 & 38 \\
New York & US & $40.7^{\circ} \mathrm{N}$ & $74.16^{\circ} \mathrm{W}$ & 79 & 23 & 41 & 16 \\
Niamey & Niger & $13.48^{\circ} \mathrm{N}$ & $2.18^{\circ} \mathrm{E}$ & 4 & 0 & 12 & 12 \\
Portland & US & $45.59^{\circ} \mathrm{N}$ & $122.6^{\circ} \mathrm{W}$ & 5 & 8 & 5 & 4 \\
Tehran & Iran & $35.69^{\circ} \mathrm{N}$ & $51.32^{\circ} \mathrm{E}$ & 8 & 11 & 31 & 18 \\
Tokyo & Japan & $35.76^{\circ} \mathrm{N}$ & $140.38^{\circ} \mathrm{E}$ & 38 & 50 & 56 & 34 \\
\hline
\end{tabular}

uiuc.edu/) network in North America, 51 from the EMEP network in Europe and 28 from EANET in eastern Asia.

\subsection{Vertical structure: ozonesondes, MOZAIC and measurement campaigns}

The surface evaluation is complemented with an assessment of the vertical structure of $\mathrm{O}_{3}$ using ozonesondes from the World Ozone and Ultraviolet Radiation Data Center ozonesonde network (WOUDC; http://woudc.org/data/ explore.php), the Global Monitoring Division (GMD; https: //www.esrl.noaa.gov/gmd/dv/ftpdata.html) and the Southern Hemisphere ADditional OZonesondes (SHADOZ; http: //croc.gsfc.nasa.gov/shadoz/; Thompson et al., 2003a, b). Most stations provide between 4 and 12 profiles per month each year with a precision of $\pm 3-8 \%$ in the troposphere (Tilmes et al., 2012). We followed the methodology of Tilmes et al. (2012) for the selection and treatment of the measurements. Table 3 lists the locations and the number of available measurements per season of the 39 ozonesonde stations used (also displayed in Fig. 1), as well as the regions where stations with similar $\mathrm{O}_{3}$ profiles were aggregated.

Additional observations considered in this study are $\mathrm{CO}$ vertical profiles from the Measurement of Ozone, Water Vapor, Carbon Monoxide, Nitrogen Oxide by Airbus In-Service Aircraft (MOZAIC; http://http://www.iagos.fr). Based on the availability of data, we selected 14 airports (displayed in Fig. 1, right panel) covering different regions of the world during 2004. The number of vertical profiles available per season are provided in Table 4.

Nitric oxide $\left(\mathrm{NO}_{x}\right)$, peroxyacetyl nitrate (PAN) and acid nitric $\left(\mathrm{HNO}_{3}\right)$ vertical profiles are used from four different measurement campaigns: TOPSE (Atlas et al., 2003; Emmons et al., 2003), TRACE-P (Jacob et al., 2003), PEMTropics-B (Raper et al., 2001) and POLINAT-2 (Schumann et al., 2000). Tropospheric data from these four previous campaigns were gridded onto global maps with resolution $5^{\circ} \times 5^{\circ} \times 1 \mathrm{~km}$, forming data composites of important chemical species in order to provide a picture of the global distributions (Emmons et al., 2000).

In this study, all the observations considered are within the simulated year (2004), with the exception of the vertical profiles obtained from measurement campaigns. Details on the geographical regions and periods for these campaigns are given in Table 5, and the locations are displayed in Fig. 1 (right panel).

\subsection{Satellite data}

Modeled tropospheric $\mathrm{NO}_{2}$ columns are compared with SCanning Imaging Absorption spectroMeter for Atmospheric CHartographY (SCIAMACHY, http://www.sciamachy.org/) satellite data. SCIAMACHY (on board of ENVISAT, which was operational from March 2002 to April 2012) is a passive remote sensing spectrometer measuring backscattered, reflected, transmitted or emitted radiation from the atmosphere and Earth's surface with a wavelength range between 240 and $2380 \mathrm{~nm}$. The SCIAMACHY instrument has a spatial resolution of typically $60 \mathrm{~km} \times 30 \mathrm{~km}$, and has three different viewing geometries: nadir, limb, and sun/moon occultation. Alternating nadir and limb views, global coverage is achieved in 6 days.

$\mathrm{NO}_{2}$ daily data were obtained from the Institute of Environmental Physics, University of Bremen (http://www.iup. uni-bremen.de/doas/scia_no2_data_tropos.htm), based on the Version 3.0 data product (Hilboll et al., 2013). This dataset is an improved extension of the data presented in Richter et al. (2005). Validation of the data product was performed in several studies (e.g., Petritoli et al., 2004; Heue et al., 2005). We used daily satellite overpasses of cloud-free 
Table 5. Description of additional aircraft campaign data, including location and date.

\begin{tabular}{llrrl}
\hline Region name & Expedition & Latitude & Longitude & Date \\
\hline Boulder & TOPSE & $37-47^{\circ} \mathrm{N}$ & $110-90^{\circ} \mathrm{W}$ & 5 Feb-23 May 2000 \\
Churchill & TOPSE & $47-65^{\circ} \mathrm{N}$ & $110-80^{\circ} \mathrm{W}$ & 5 Feb-23 May 2000 \\
China & TRACE-P & $10-30^{\circ} \mathrm{N}$ & $110-130^{\circ} \mathrm{E}$ & 24 Feb-10 Apr 2001 \\
Hawaii & TRACE-P & $10-30^{\circ} \mathrm{N}$ & $170-150^{\circ} \mathrm{W}$ & 24 Feb-10 Apr 2001 \\
Japan & TRACE-P & $20-40^{\circ} \mathrm{N}$ & $130-150^{\circ} \mathrm{E}$ & 24 Feb-10 Apr 2001 \\
Tahiti & PEM-Tropics-B & $20^{\circ} \mathrm{S}-0$ & $160-130^{\circ} \mathrm{W}$ & 6 Mar-18 Apr 1999 \\
Ireland & POLINAT-2 & $50-60^{\circ} \mathrm{N}$ & $15-5^{\circ} \mathrm{W}$ & 19 Sep-25 Oct 1997 \\
\hline
\end{tabular}

$(<20 \%$ cloud fraction) tropospheric vertical column densities (VCDtrop $\mathrm{NO}_{2}$ ) from SCIAMACHY measurements using the limb-nadir matching approach, whose total uncertainty is estimated to vary between 35 and $60 \%$ in heavily polluted cases and $>100 \%$ in clean scenarios (Boersma et al., 2004).

Additionally, $\mathrm{CO}$ mixing ratios at 800 and $500 \mathrm{hPa}$ were evaluated with the Measurement of Pollution in the Troposphere (MOPITT, http://www2.acd.ucar.edu/mopitt) instrument retrievals. MOPITT, on board of the NASA EOS-Terra satellite, is a gas filter radiometer and measures thermal infrared (near $4.7 \mu \mathrm{m}$ ) and near-infrared (near $2.3 \mu \mathrm{m}$ ) radiation, only during clear-sky conditions, with a ground footprint of about $22 \mathrm{~km} \times 22 \mathrm{~km}$. We used the MOPITT Version 5 (V5) Level 2 data product, which provides daily CO mixing ratios. MOPITT CO mixing ratios have been validated with in situ CO profiles measured from numerous NOAA/ESRL aircraft profiles in Deeter et al. (2013), and they were found to be positively biased by about $1 \%$ and highly correlated $(r=0.98)$ at surface levels.

\section{Model evaluation}

This section presents the model evaluation with observations of relevant trace gases, and compares the results with other modeling studies available in the literature.

For the evaluation of daily surface-level $\mathrm{O}_{3}$, we considered averages of temporally collocated 3-hourly values from the model and the observations. Section S1 of the Supplement presents the statistical measures calculated from the daily data. Ground-monitoring stations were selected with a maximum altitude of $1000 \mathrm{~m}$. Temporal collocation was also considered when comparing to ozonesondes, MOZAIC, MOPITT and SCIAMACHY. For CO, averaging kernels were considered to represent the observational sensitivity at different pressure levels. When computing the modeled tropospheric columns of $\mathrm{NO}_{2}$ the tropopause was assumed to be fixed at $100 \mathrm{hPa}$ in the tropics and $250 \mathrm{hPa}$ in the extratropics.

Similarly, the evaluation with aircraft campaigns was performed after remapping the model output to the resolution of the observed data composites $\left(5^{\circ} \times 5^{\circ} \times 1 \mathrm{~km}\right)$. For some species, the model evaluation is given per sea- sons: December-January-February (DJF), March-AprilMay (MAM), June-July-August (JJA) and SeptemberOctober-November (SON).

\subsection{Hydroxyl radical $(\mathrm{OH})$}

One of the means for characterizing the general properties of an AQM is through its ability to simulate $\mathrm{OH}$ oxidation. $\mathrm{OH}$ is the main oxidant in the troposphere and is responsible for the removal of many compounds, thereby controlling their atmospheric abundance and lifetime. $\mathrm{OH}$ is mostly found in the tropical lower and mid troposphere and strongly depends on the levels of ultraviolet radiation and water vapor. Tropospheric $\mathrm{OH}$ formation is mainly due to $\mathrm{O}_{3}$ photolysis, dominated by the tropics. Also, $\mathrm{OH}$ is directly connected to the chemistry of $\mathrm{O}_{3}$ production since the initial reactions of $\mathrm{O}_{3}$ formation $(\mathrm{VOC}+\mathrm{OH}$ and $\mathrm{CO}+\mathrm{OH})$ are driven by $\mathrm{OH}$. Hence, $\mathrm{O}_{3}$ production rates depend on the sources and sinks of odd hydrogen radicals. Primary $\mathrm{OH}$ formation also includes the photolysis of HCHO and secondary VOC.

The tropospheric mean (air mass weighted) $\mathrm{OH}$ derived by the model is $11.5 \times 10^{5} \mathrm{molec}^{-3}$, assuming a tropospheric domain ranging from $200 \mathrm{hPa}$ to the surface. Note that previous studies suggest that the estimation of the mean $\mathrm{OH}$ does not depend on the definition of the tropopause (Voulgarakis et al., 2013). This value is in good agreement with other studies, e.g., Voulgarakis et al. (2013), where the mean $\mathrm{OH}$ concentration from 14 models for 2000 was estimated to be $11.1 \pm 1.8 \times 10^{5} \mathrm{molec}^{-3}$, Spivakovsky et al. (2000) with $11.6 \times 10^{5} \mathrm{molec} \mathrm{cm}^{-3}$, and Prinn et al. (2001) with $9.4 \pm 0.13 \times 10^{5}$ molec cm $^{-3}$.

The zonal mean OH concentrations for January, April, July and October 2004 are shown in Fig. 2. Seasonal differences reflect the impact of water vapor concentration and stratospheric $\mathrm{O}_{3}$ column upon incident ultraviolet (UV) radiation (Spivakovsky et al., 2000; Lelieveld et al., 2002). The highest $\mathrm{OH}$ concentrations arise in the tropics throughout the year. In northern mid-latitudes, the highest $\mathrm{OH}$ concentrations are found during summer in the lower to middle troposphere. The latitudinal and seasonal variations are similar to the climatological mean in Spivakovsky et al. (2000), particularly the lower values in the extratropics. Peak concentrations are slightly larger compared to this climatology and other stud- 

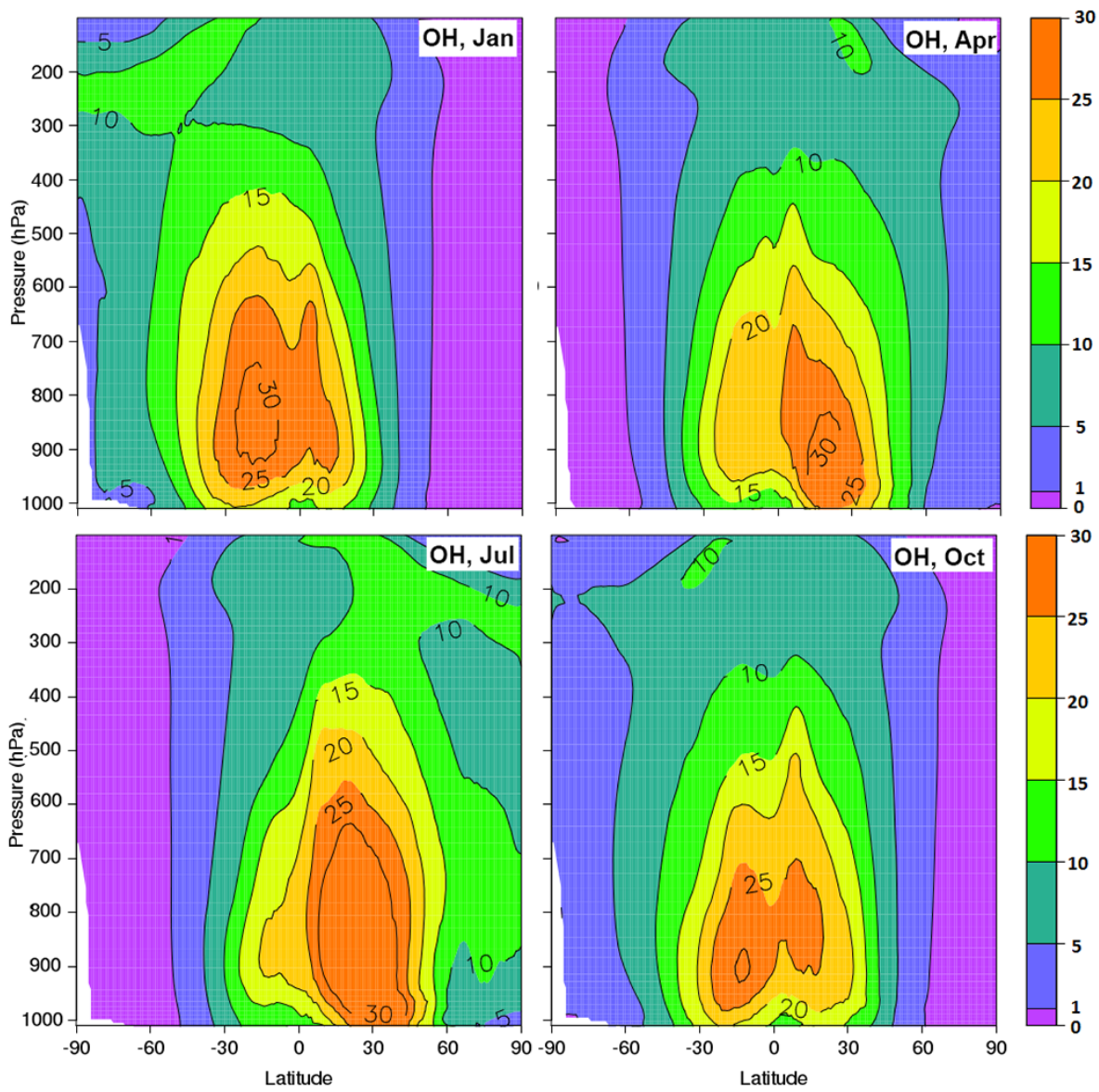

Figure 2. Zonal monthly mean $\mathrm{OH}$ concentrations $\left(10^{5}\right.$ molec $\left.\mathrm{cm}^{-3}\right)$ for January, April, July and October by the NMMB-MONARCH model.

ies (e.g., Horowitz et al., 2003; Huijnen et al., 2010). During January and October the peaks appear in the southern tropics between $700-1000$ and $800-1000 \mathrm{hPa}$, respectively. The peak in April and July is found in the northern tropics between 800-1000 and 700-1000 hPa, respectively.

The mean $\mathrm{OH}$ inter-hemispheric $(\mathrm{N} / \mathrm{S})$ ratio of the model is 1.18. This quantity is comparable with the present-day multi-model mean ratio $(1.28 \pm 0.1)$ shown in Naik et al. (2013b). In addition, the model regional annual mean air mass-weighted $\mathrm{OH}$ concentrations have been calculated and are in general agreement with the multi-model values (Naik et al., 2013b) (see Fig. S2). However, concentrations over the tropics $\left(30^{\circ} \mathrm{S}-30^{\circ} \mathrm{N}\right)$ are slightly higher than the multimodel mean and concentrations above $500 \mathrm{hPa}$ are lower than the multi-model mean. Labrador et al. (2004) studied the sensitivity of $\mathrm{OH}$ to $\mathrm{NO}_{x}$ from lightning, showing that $\mathrm{OH}$ concentrations increase mostly in the middle to upper troposphere $(500-200 \mathrm{hPa})$ if lightning emissions are considered. Therefore, the lack of lightning emissions in our model run could at least partly explain the lower $\mathrm{OH}$ values above $500 \mathrm{hPa}$ reported here. Another potential explanation is the lack of aerosols in our simulation, which may overestimate photolysis rates in polluted regions (e.g., Bian et al., 2003; Real and Sartelet, 2011).

\subsection{Carbon monoxide (CO)}

$\mathrm{CO}$ is one of the most important trace gases in the troposphere, exerting a significant influence upon the concentration of oxidants such as $\mathrm{OH}$ and $\mathrm{O}_{3}$ (Wotawa et al., 2001). The main sources of $\mathrm{CO}$ in the troposphere are the photochemical production from the oxidation of hydrocarbons (including methane) and direct emissions, mainly fossil fuel combustion, biomass burning and biogenic emissions. $\mathrm{CO}$ main loss is by reaction with $\mathrm{OH}$, which occurs primarily in the tropics, but also in the extratropics.

In the northern extratropics, the elevated $\mathrm{CO}$ concentrations are dominated by anthropogenic emissions and precursor hydrocarbons, which leads to a net $\mathrm{CO}$ export to the tropics (Shindell et al., 2006; Bergamaschi et al., 2000). Although most of the biomass burning occurs in the tropics, gases and aerosols emitted from large wildfires can be transported to the southern extratropics, where emissions and chemical production are lower. Also, due to strong convec- 
Table 6. Annual mean burden of tropospheric CO (Tg CO) in the NMMB-MONARCH, MOZART-2, TM5 and C-IFS global models.

\begin{tabular}{lrrrrrrrr}
\hline & \multicolumn{8}{c}{ Burden } \\
\cline { 2 - 6 } Model & Global & NH & SH & Trop. & N. extratrop. & S. extratrop. & Dry depo. & Reference \\
\hline NMMB-MONARCH & 399 & 221 & 177 & 229 & 101 & 67 & 24 & This study \\
MOZART-2 & 351 & 210 & 142 & 199 & 102 & 50 & 2 & Horowitz et al. (2003) \\
TM5 & 353 & - & - & 188 & 106 & 59 & 184 & Huijnen et al. (2010) \\
C-IFS & 361 & - & - & - & - & - & - & Flemming et al. (2015) \\
\hline
\end{tabular}

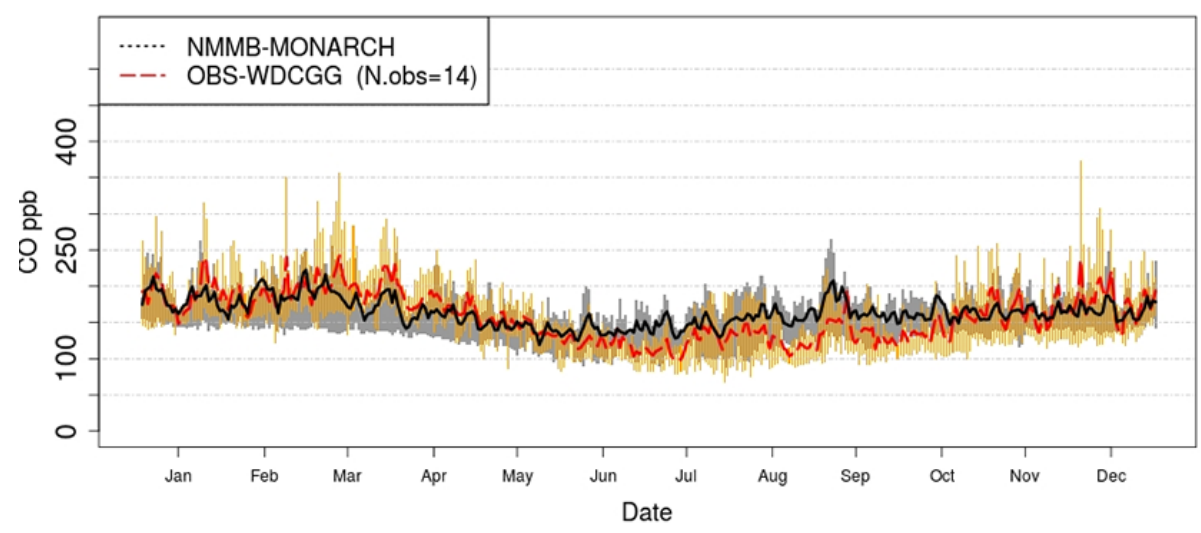

Figure 3. Time series of CO daily mean concentration in ppb averaged over all the rural WDCGG stations used. Observations are depicted with a solid red line and model data with a solid black line. Bars show the 25th-75th quartile interval for observations (orange bars) and the model (gray bars).

tion enhanced by forest fire activity, emissions can reach the upper troposphere and the lower stratosphere (Jost et al., 2004; Cammas et al., 2009). CO has a chemical lifetime of a few months $(\sim 1-3)$, and therefore it is a useful tracer for evaluating transport processes in the model. It is important to keep in mind that despite large Alaskan and Canadian wildfires that occurred during the summer, globally 2004 had lower $\mathrm{CO}$ concentrations than other years during the decade (Elguindi et al., 2010).

An analysis of the $\mathrm{CO}$ burden in different regions is presented in Table 6. The global and annual mean burden of CO for 2004 is $399.03 \mathrm{Tg}$, with higher abundances in the tropics $(229.43 \mathrm{TgCO})$, followed by the northern extratropics (101.71 Tg CO), and the southern extratropics (67.88 Tg CO). Other model estimates of the $\mathrm{CO}$ burden (Horowitz et al., 2003; Huijnen et al., 2010; Flemming et al., 2015) are also shown in Table 6. Our estimates are higher by $\sim 46-48 \mathrm{Tg}$ CO compared to these studies, and it happens in all regions. The largest absolute difference appears in the tropics where the NMMB-MONARCH predicts $\sim 30-40 \mathrm{Tg}$ CO more than these studies, even though $\mathrm{OH}$ is also overestimated. The main sources of $\mathrm{CO}$ in the tropics are from biomass burning, biogenic emissions and anthropogenic direct emissions of $\mathrm{CO}$.

We performed tests comparing the annual mean burden of tropospheric $\mathrm{CO}$ with and without biomass burning emis- sions in the model. Neglecting biomass burning emissions only reduced $7 \%$ of the tropospheric $\mathrm{CO}$ annual mean burden. Therefore, other factors should explain our higher $\mathrm{CO}$ burden. On the one hand, biogenic emissions are computed online every hour in order to account for evolving meteorological changes such as solar radiation and surface temperature (see Sect. 2.2.6). Also, this simulation neglects the attenuation of radiation due to aerosols, which may produce an overestimation of VOC biogenic emissions and the derived CO.

The CO anthropogenic emissions used in this study $\left(610.5 \mathrm{Tg} \mathrm{year}^{-1}\right)$ are also higher than those in other inventories (see Sect. 3.1). The dry deposition of $\mathrm{CO}$ is significantly weaker in the NMMB-MONARCH $(24 \mathrm{Tg} \mathrm{CO})$ than the global model TM5 (184 Tg CO) and the study of Bergamaschi et al. (2000) (292-308 Tg CO). By contrast, other global models such as MOZART-2 have significantly lower dry deposition (2 $\mathrm{Tg} \mathrm{CO}$ ) and the study of Wesely and Hicks (2000) suggests that CO and other relatively inert substances are deposited very slowly. Clearly, there are major uncertainties in the sources and sinks of CO that could be responsible for modeled $\mathrm{CO}$ differences.

Figure 3 shows the time series of $\mathrm{CO}$ daily mean concentration over 14 ground-monitoring stations from the WDCGG database (primarily in the northern mid-latitudes, but with a few of them in the tropics and southern mid-latitudes). 

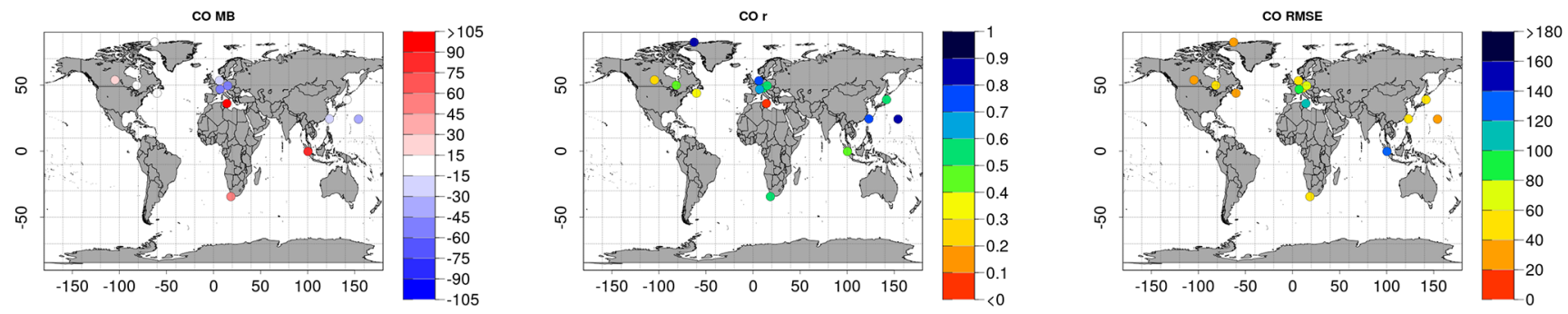

Figure 4. CO spatial distribution of mean bias (MB, ppb) (left panel), correlation ( $r$ ) (middle panel) and root mean square error (RMSE, $\mathrm{ppb}$ ) (right panel) at all the rural WDCGG stations used.

The solid red line and the solid black line represent, respectively, the average of observations and the model simulation. Bars show the 25th-75th quartile interval of all observations (orange) and the model simulation (gray). The model is in good agreement with the $\mathrm{CO}$ field in the surface layer (daily correlations between 0.3 and 0.7 ). However, the model is not able to fully capture the seasonal $\mathrm{CO}$ variability, with a slight underestimation during cold months $(-10.65 \mathrm{ppb})$ and overestimation during warm months $(28.67 \mathrm{ppb})$. Such a model limitation could be explained by the fact that most of the stations are closer to anthropogenic polluted areas, where its concentration is primarily determined by local emissions, and the CO land-based anthropogenic emissions inventory does not have any seasonal variation in this study (see Sect. 3.1).

Figure 4 shows the $\mathrm{CO}$ mean bias (MB), correlation and root mean square error for all rural WDCGG stations. The model has a negative MB over stations in Europe and Japan and a positive bias in stations in Canada and Africa, where the correlations are low. The negative bias for several of the northern mid-latitude stations indicates that the higher $\mathrm{CO}$ burden found in our model compared to other models in these areas is a feature mainly driven by free tropospheric abundances. Higher correlations are found in northern regions of Europe, southern Africa and eastern Asian countries. The daily correlation in Canadian stations is between 0.3 and 0.5 . In most of the stations, the RMSE is found to be less than 60$40 \mathrm{ppb}$, with only four stations having a RMSE higher than $60 \mathrm{ppb}$.

Additionally, the model was compared with seasonally averaged vertical profiles of temporally collocated $\mathrm{CO}$ from MOZAIC aircraft observations from selected airports: Frankfurt, Beijing, Atlanta, Portland, Abu Dhabi and Niamey (shown in Figs. 5 and S3). Observations and model results (both mean and standard deviation) are represented in red and black, respectively. We note that the number of flights differ among airports (therefore not all comparisons are statistically robust), and the $\mathrm{CO}$ range represented for Beijing is larger $(0-1000 \mathrm{ppb})$ than for other stations $(0-400 \mathrm{ppb})$. The model captures reasonably well the vertical profiles during the first part of the year and shows larger biases during the warm months. It overestimates $\mathrm{CO}$ from the mid- dle to the upper troposphere in most stations throughout the year. Over Frankfurt, the model is in good agreement with the observations during the entire year, despite slight underestimations during MAM ( $\sim-31 \mathrm{ppb})$ and overestimations during SON $(\sim 12 \mathrm{ppb})$ in the middle troposphere. For Beijing, one of the most polluted cities in the world, the model shows a clear tendency to underestimate $\mathrm{CO}$ in the lower atmosphere (below $600 \mathrm{hPa}$ ). This is very probably due to an underestimation of $\mathrm{CO}$ anthropogenic emissions. Most AQMs are unable to capture the extreme growth of anthropogenic emissions in China (Akimoto, 2003; Turquety et al., 2008). Over Atlanta, the model performs better in winter and spring throughout the troposphere than in summer and autumn, when positive biases reach $\sim 20-25 \mathrm{ppb}$. In regions with biomass burning and biogenic influence, such as Abu Dhabi and Niamey, the model significantly overestimates CO during warm months throughout the tropospheric column. During winter and spring, Stein et al. (2014) also obtain an underestimation of $\mathrm{CO}$ vertical profiles in airports located in the Northern Hemisphere (NH).

To complete this $\mathrm{CO}$ evaluation, seasonal averages are compared with data from the MOPITT instrument at 800 and $500 \mathrm{hPa}$ (Figs. 6 and S4, respectively). At $800 \mathrm{hPa}$, the largest differences are detected during boreal winter and spring, when the model clearly overestimates in the tropics and underestimates in the northern extratropics and northern Africa. The wintertime negative bias $(\sim-10-35 \mathrm{ppb})$ in the $\mathrm{NH}$ may be explained by either the lack of seasonally varying anthropogenic emissions in our simulation, an underestimation of CO emissions (Stein et al., 2014), or a combination thereof. There are significant positive biases over westerncentral Africa, western South America, Indonesia and the surrounding Pacific and Indian oceans during the dry season. Sources of $\mathrm{CO}$ over western-central Africa are mainly from biomass burning and biogenic emissions. Uncertainties in the emission inventories probably contribute to the $\mathrm{CO}$ overestimation in these regions. Due to the long-range transport of $\mathrm{CO}$, higher concentrations are also seen throughout the year over the tropics and some parts of the extratropics from June to November. During JJA and SON the model overestimates $\mathrm{CO}$ in most places, including southern and central Europe and the US ( 10-25 ppb). At $500 \mathrm{hPa}$, the model presents 

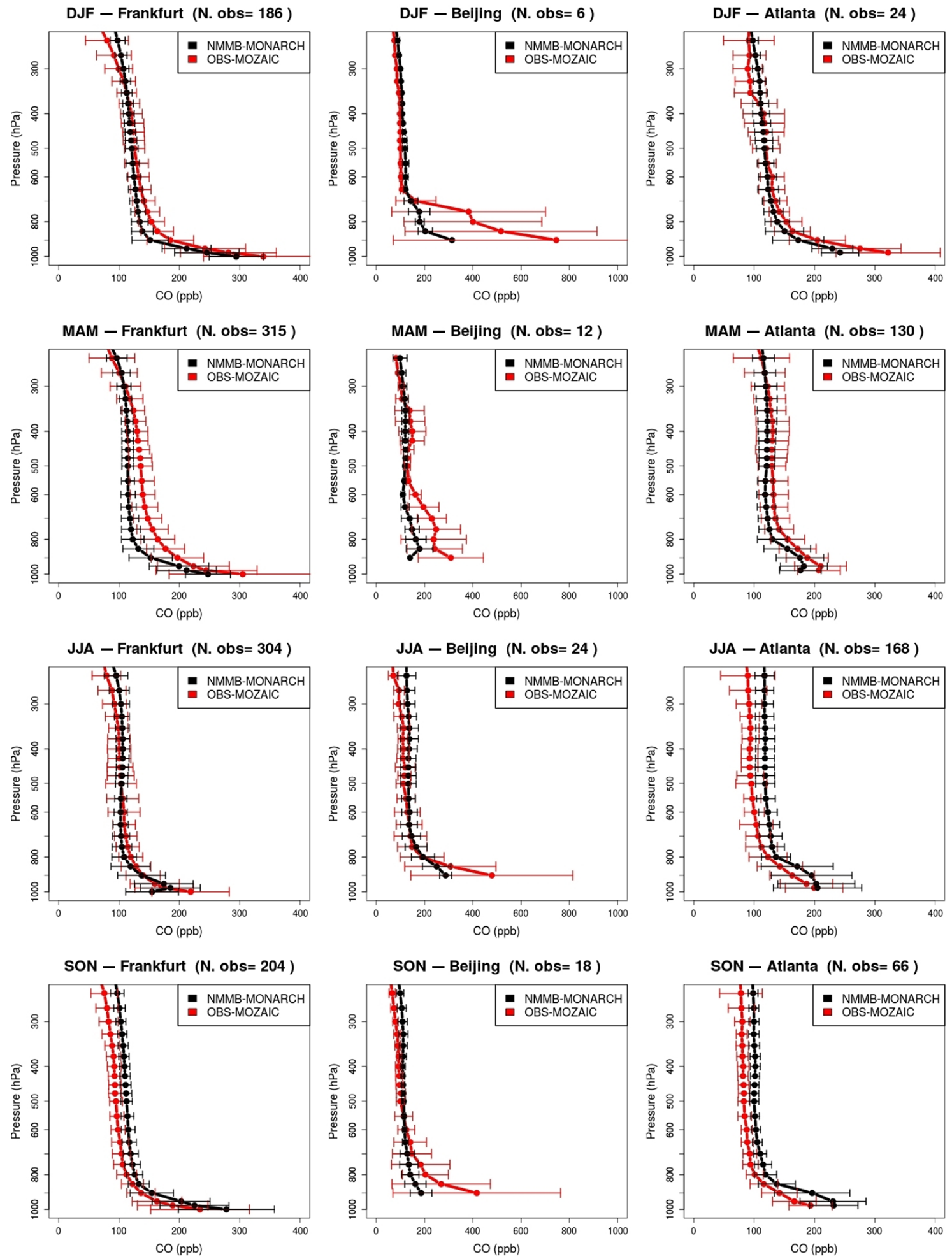

Figure 5. CO vertical profile seasonal averages over Frankfurt, Beijing and Atlanta (from left to right) for the year 2004 from MOZAIC. Observations depicted with a solid red line and the model with a solid black line. Horizontal lines show the standard deviations. The number of flights is provided on the top of each plot. 

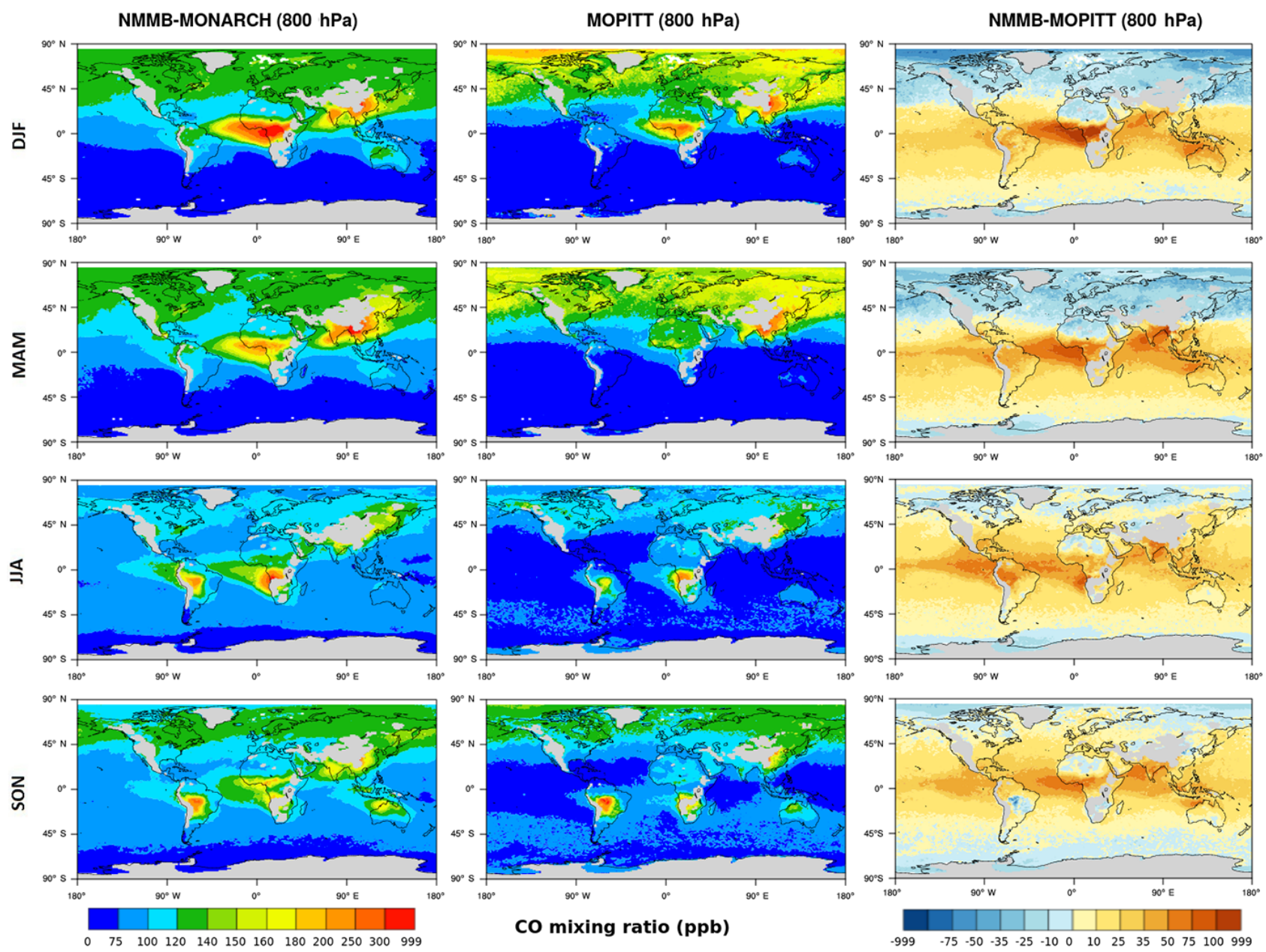

Figure 6. Comparison of the modeled CO mixing ratio at $800 \mathrm{hPa}$ against satellite data (MOPITT) in ppb. From top to bottom: DJF for December-January-February, MAM for March-April-May, JJA for June-July-August and SON for September-October-November for the year 2004. NMMB-MONARCH data are displayed in the left panel, MOPITT data in the middle panel, and the bias in the right panel.

similar results, with clear underestimations in the northern extratropics and overestimations in the tropics and southern latitudes. Excessive vertical mixing by moist convection may explain the overestimation in the tropics. Overestimated emissions in Africa or Asia above the PBL could also lead to this positive bias in the middle of the troposphere.

Naik et al. (2013b) compared the multi-model annual mean from 17 models for the year 2000 with the average $\mathrm{CO}$ from MOPITT at $500 \mathrm{hPa}$ between 2000 and 2006. The 17 models used the same anthropogenic and biomass burning emissions as our model, and a priori and averaging kernels were taken into account for each model before computing the biases. The biases in the tropics and extratropics are similar to those presented here, suggesting systematic model errors due to inaccurate anthropogenic and biomass burning emission inventories. We note that MOPITT V4 CO retrievals are affected by biases of about $-6 \%$ at $400 \mathrm{hPa}$ when evaluated with in situ measurements (Deeter et al., 2010), which are low compared to current model discrepancies. Naik et al. (2013b) also discussed how an overestimated OH concentration may lead to the northern mid-latitude underestimation of CO. This may partly explain our results given the higher $\mathrm{OH}$ concentration simulated by our model compared to other models. Numerous studies show significant differences in $\mathrm{CO}$ among AQMs, which may emerge from a variety of uncertainties, including those in emission inventories and injection heights (Elguindi et al., 2010; Shindell et al., 2006; Prather et al., 2001). For example, Stein et al. (2014) suggest that the persistent negative bias in northern mid-latitude $\mathrm{CO}$ in models is most likely due to a combination of too low road traffic emissions and dry-deposition errors.

\subsection{Nitrogen compounds}

The $\mathrm{NO}_{x}\left(=\mathrm{NO}_{2}+\mathrm{NO}\right)$ family is one of the key players in the formation of $\mathrm{O}_{3}$ in the troposphere, causing photochemical smog and contributing to acid rain during pollution episodes. Because it has a relatively short lifetime (a few 

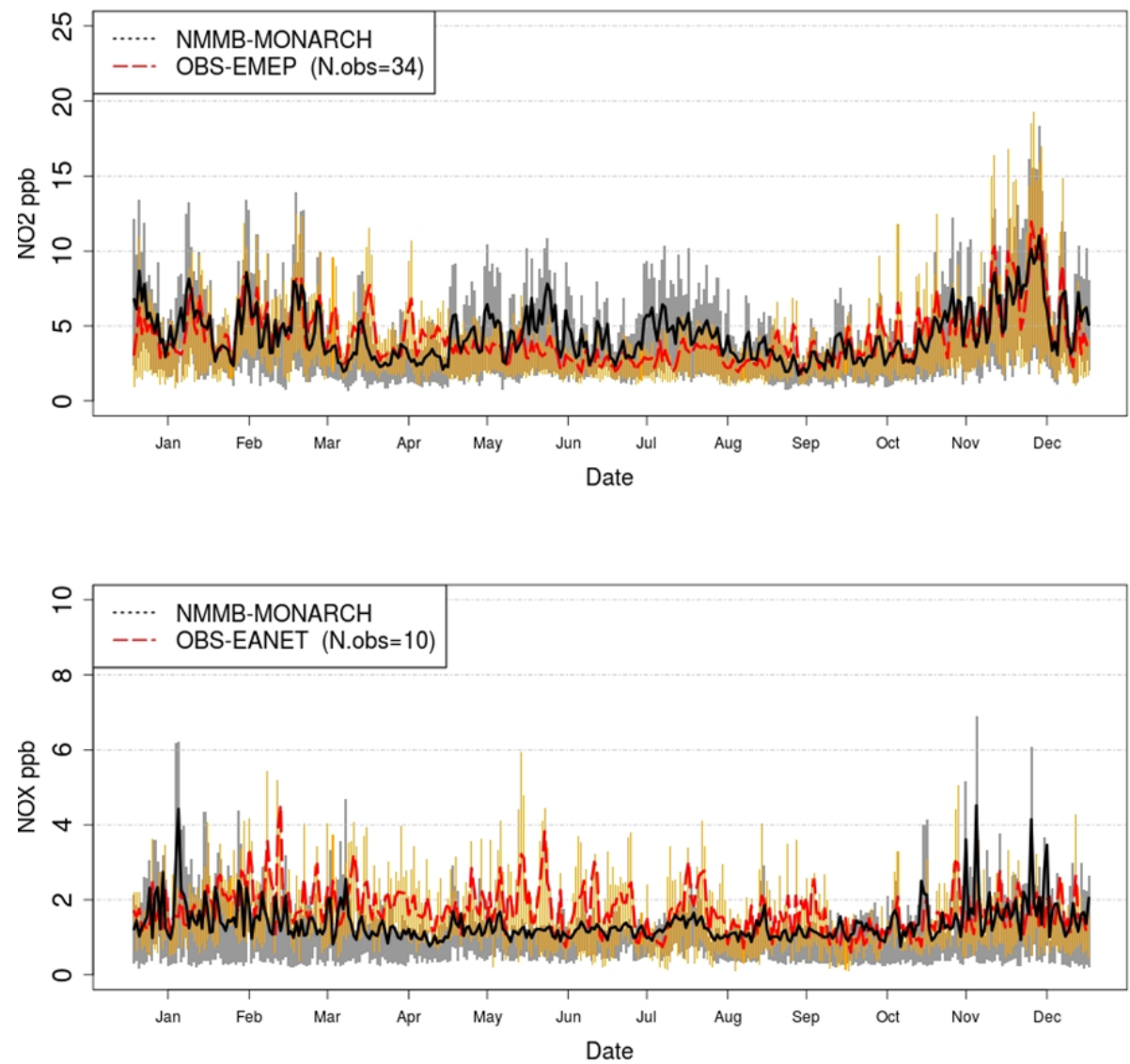

Figure 7. Time series of $\mathrm{NO}_{2}$ (top) and $\mathrm{NO}_{x}$ (bottom) daily mean concentration averaged over the rural EMEP and EANET stations, respectively, in ppb. Observations are depicted with a solid red line and model data with a solid black line. Bars indicate the 25th-75th quartile interval for observations (orange bars) and model (gray bars).

hours within the PBL and up to a few days in the upper troposphere; Tie et al., 2001, 2002), it is generally restricted to emission sources, both natural and anthropogenic (mainly fossil fuel combustion). The seasonal cycle of $\mathrm{NO}_{x}$ near the surface is controlled by the seasonality of anthropogenic emissions (especially in the $\mathrm{NH}$ ) and biomass burning emissions (especially in the tropics and the Southern Hemisphere $(\mathrm{SH})$ ). As a result, $\mathrm{NO}_{x}$ concentration is more sensitive to errors in emissions than other pollutants (Miyazaki et al., 2012).

Figure 7 shows the time series of $\mathrm{NO}_{2}$ and $\mathrm{NO}_{x}$ daily mean surface concentrations over 21 EMEP and 10 EANET rural ground-monitoring stations. In both cases the model is able to successfully reproduce the seasonal cycle of $\mathrm{NO}_{2}$ and $\mathrm{NO}_{x}$. However, a positive bias $(<3 \mathrm{ppb})$ is found during summertime for $\mathrm{NO}_{2}$ in Europe (Fig. 7, top panel), which may result from the lack of seasonality in the anthropogenic emissions. The modeled $\mathrm{NO}_{2}$ concentration is excessive during nighttime (not shown). This may result from the lack of heterogeneous formation of $\mathrm{HNO}_{3}$ through $\mathrm{N}_{2} \mathrm{O}_{5}$ hydrolysis, an important sink of $\mathrm{NO}_{2}$ at night. In addition, the model does not consider secondary aerosol formation in the present study, resulting in an excessively oxidizing atmosphere (overestimation of $\mathrm{OH}$ radicals) that in turn may lead to an accumulation of $\mathrm{NO}_{2}$ near the surface. Between 09:00 and 18:00 UTC there is a slight underestimation of $\mathrm{NO}_{2}$. In Asia (Fig. 7 bottom) the model does not reproduce the observed $\mathrm{NO}_{x}$ values, showing a large negative bias during the summer probably due to underestimated emissions (Akimoto, 2003; Richter et al., 2005), as in the case of CO. Also, an excessive mixing within the PBL during the night could contribute to a decrease in ozone titration by $\mathrm{NO}$ and explain the bias.

The model correlation is lower in regions such as the Iberian Peninsula and most of the stations in Japan (Fig. 8). The best performance occurs in central Europe and stations in Japan that are not in the main island. In general there is a negative bias in most of the stations for these two regions.

Figure 9 displays the comparison of $\mathrm{NO}_{x}, \mathrm{HNO}_{3}$ and PAN vertical profiles for several regions in the US, China, Hawaii and Japan (see Table 5). The comparison over Tahiti and Ireland is shown in Fig. S5. As explained in Sect. 4.2, the observed vertical profiles do not correspond to the simulated year (see Table 5 for more details), but the qualitative patterns 

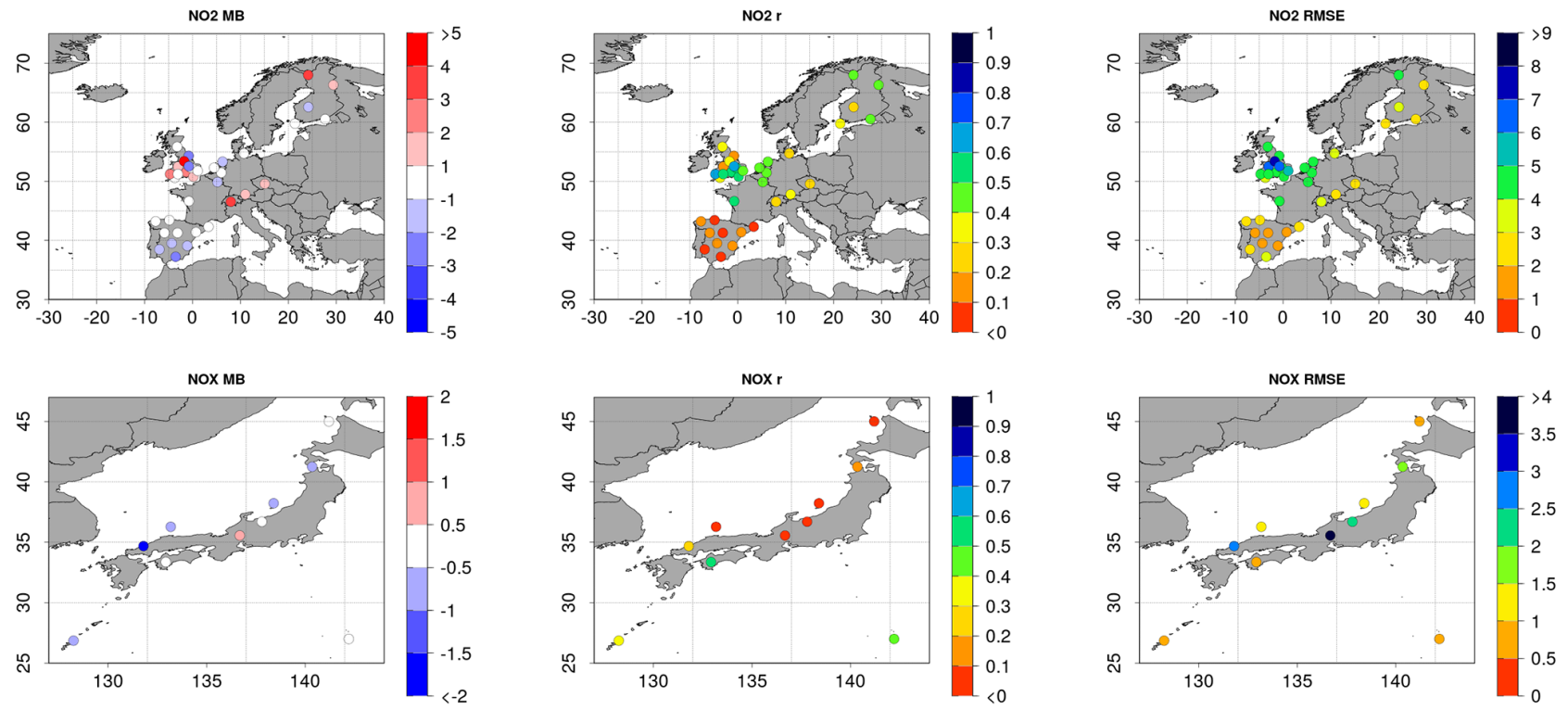

Figure 8. $\mathrm{NO}_{2}$ (top) $\mathrm{NO}_{x}$ (bottom) and spatial distribution of mean bias (MB, ppb) (left panel), correlation ( $r$ ) (middle panel) and RMSE (ppb) (right panel) at all rural EMEP and EANET stations, respectively.

can provide insights on the model capability to reproduce the chemistry involved. Figure 9 (first column) shows that vertical profiles of $\mathrm{NO}_{x}$ are really well captured by the model. The model has a tendency to overestimate $\mathrm{NO}_{x}$ concentrations near the surface $(\sim 400 \mathrm{ppt}$ in Japan and $\sim 300 \mathrm{ppt}$ in China); it is likely that $\mathrm{NO}_{x}$ emissions used in this study are higher than the actual emissions during the campaign periods. Another reason for these higher values over island locations (Japan and Hawaii) could be that emissions are spread over the coarse model grid box while the measurements were taken in the cleaner marine boundary layer. In the middle and upper troposphere, the model produces the concentrations well, with a slight underestimation in most of the locations. Note that $\mathrm{NO}_{x}$ lightning emissions are not included in this simulation, which may explain part of this underestimation, particularly in the upper troposphere.

PAN is the main tropospheric reservoir species for $\mathrm{NO}_{x}$ with important implications for the tropospheric $\mathrm{O}_{3}$ production and the main atmospheric oxidant, $\mathrm{OH}$ (Singh and Hanst, 1981). PAN is mainly formed in the boundary layer by oxidation of NMVOCs in the presence of $\mathrm{NO}_{x}$. NMVOCs and $\mathrm{NO}_{x}$ have both natural and anthropogenic sources. Rapid convection can transport PAN to the middle and upper troposphere and enables the long-range transport of $\mathrm{NO}_{x}$ away from the urban and polluted areas, where it can produce $\mathrm{O}_{3}$ and $\mathrm{OH}$ remotely.

Some features of the vertical profiles are well captured by the model, although it significantly overestimates PAN concentrations (see Fig. 9, third column). We find overestimations from the surface to the middle atmosphere in Japan, China, Boulder and Churchill, which are possibly explained by an overestimation of biogenic and anthropogenic $\mathrm{NO}_{x}$ surface emissions. Another possibility for this overestimation is an excessive lifetime of PAN. In most sites, the modeled PAN concentration tends to increase with altitude, reaching maximum mixing ratios at about $6 \mathrm{~km}$, from where it progressively decreases. This behavior explains the long thermal decomposition time of PAN (lifetime of approximately a month) and the slow loss by photolysis in the cold middleupper troposphere. Fischer et al. (2014) analyze the sensitivity of PAN to different emission types, showing that most of the NH and Japan are more sensitive to anthropogenic emissions, while the SH and the western coast of the US are more sensitive to biogenic emissions, both contributing 70-90\% of the PAN concentrations.

$\mathrm{HNO}_{3}$ is mainly produced by the reactions of $\mathrm{NO}_{2}$ with $\mathrm{OH}$ and by the heterogeneous hydrolysis of $\mathrm{N}_{2} \mathrm{O}_{5}$ (we do not account for the latter in this simulation), and removed by wet and dry deposition. $\mathrm{HNO}_{3}$ is the main sink of $\mathrm{NO}_{x}$ chemistry. In general, the modeled and observed nitric acid concentrations are of the same magnitude throughout the troposphere, although the model tends to overestimate $\mathrm{HNO}_{3}$ concentrations, particularly in US regions. In the regions of Hawaii, Japan and China the model overestimates $\mathrm{HNO}_{3}$ in the lowermiddle troposphere (up to $5 \mathrm{~km}$ ) and underestimates it in the upper troposphere (above $6 \mathrm{~km}$ ). Overestimation of $\mathrm{HNO}_{3}$ in the troposphere is a common problem in global models (Hauglustaine et al., 1998; Bey et al., 2001; Park et al., 2004; Folberth et al., 2006). $\mathrm{HNO}_{3}$ concentrations are highly sensitive to the parameterization of wet deposition. One possible reason for this overestimation is that the scavenging from convective precipitation is underestimated. 

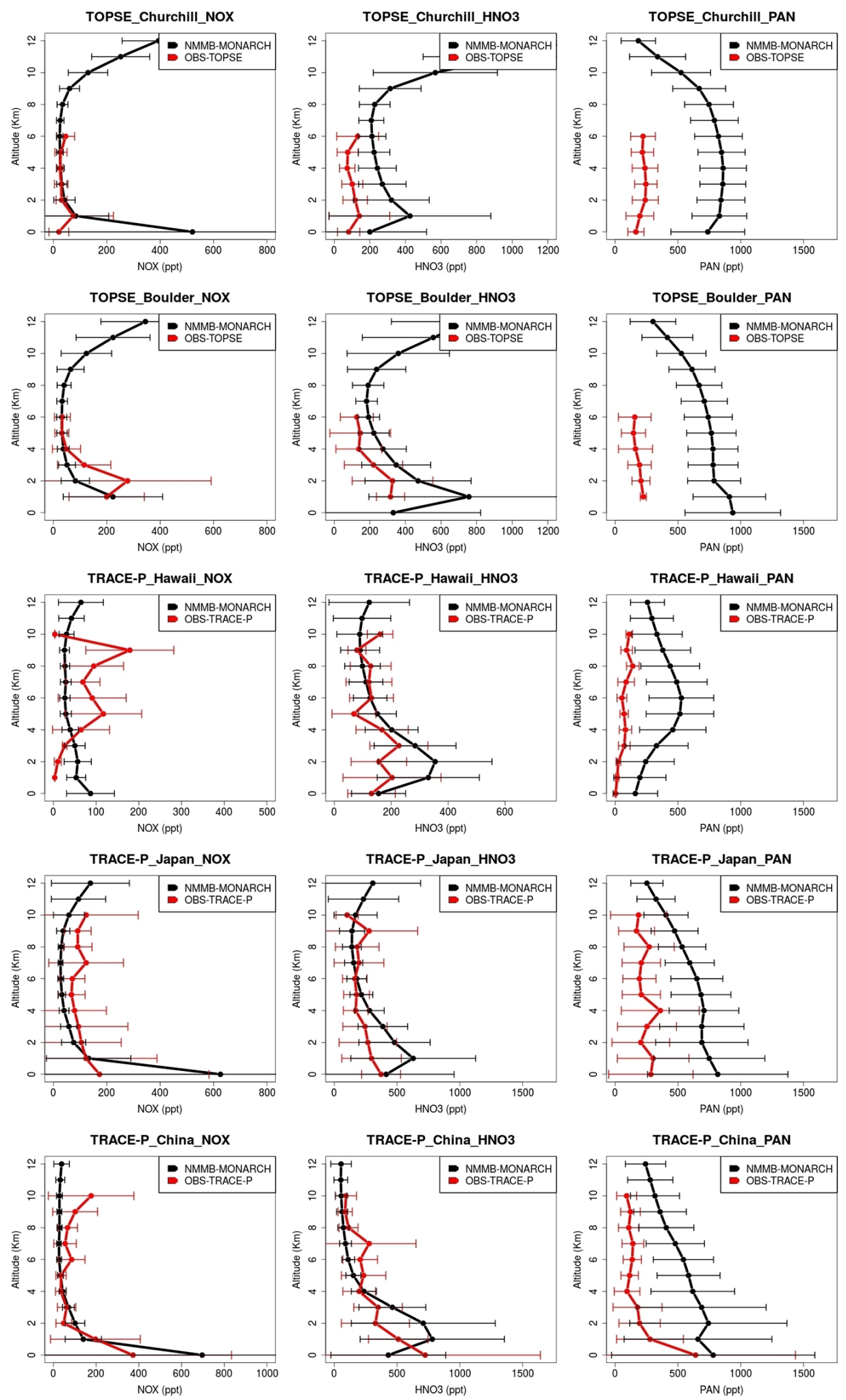

Figure 9. Comparison of modeled (black lines) and observed (red lines) vertical profiles of $\mathrm{NO}_{x}$ (first column), $\mathrm{HNO}_{3}$ (second column) and PAN (third column) for several regions in the US, China, Hawaii and Japan. Horizontal lines show the standard deviations. 

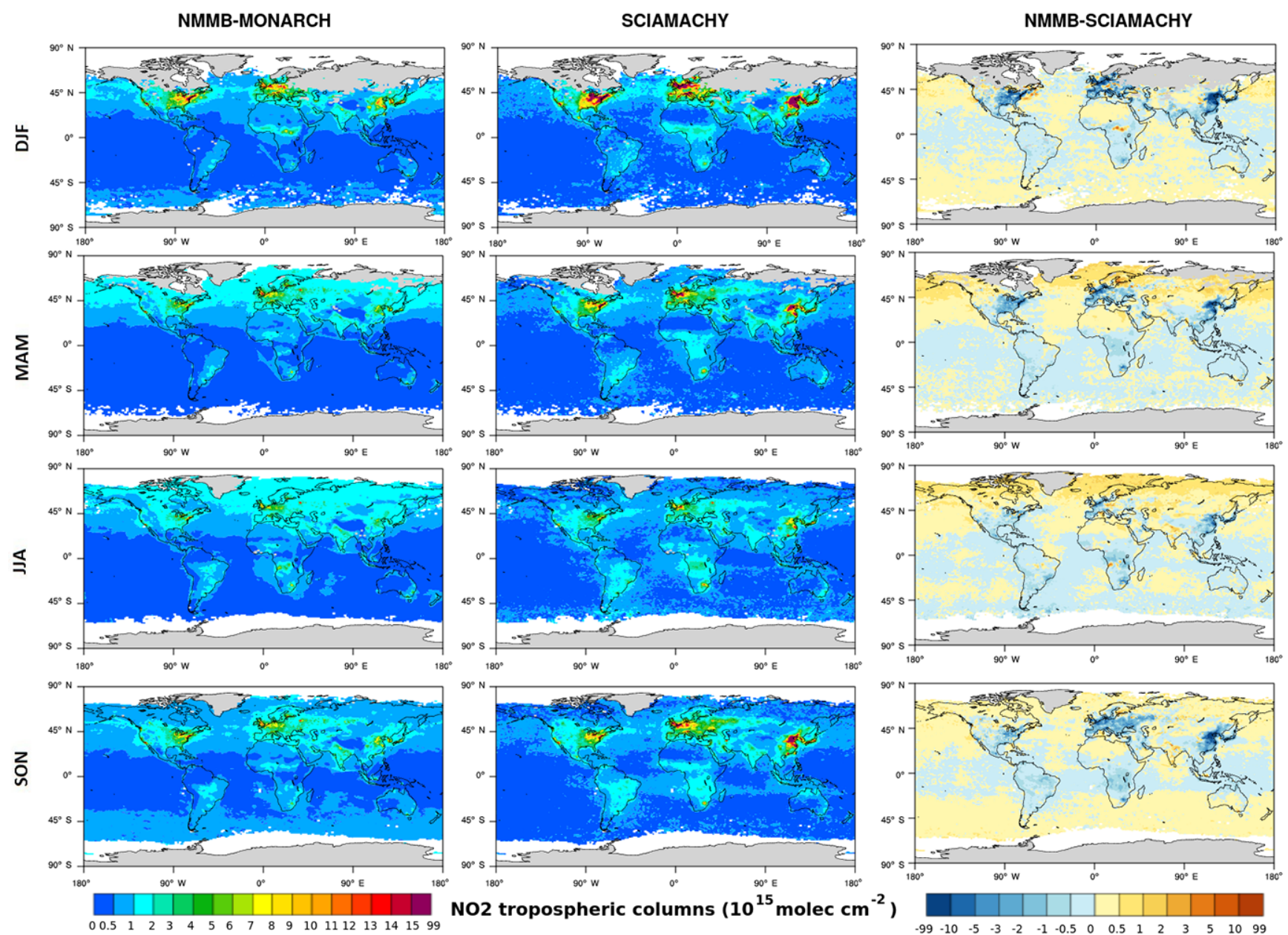

Figure 10. Comparison of modeled NMMB-MONARCH NO 2 vertical tropospheric columns against satellite data (SCIAMACHY) in $10^{15}$ molec $\mathrm{cm}^{-2}$. From top to bottom: DJF, MAM, JJA, and SON for year 2004. NMMB-MONARCH data are displayed in the left panel, SCIAMACHY data in the middle panel and the bias in the right panel.

Figure S6 evaluates the wet deposition fluxes of $\mathrm{HNO}_{3}$ with nitrate observations in Europe, the US and Asia. Satisfactory agreement is found in the $\mathrm{HNO}_{3}$ wet deposition fluxes, with correlations of 0.63 in Europe, 0.80 in the US and 0.52 in Asia. There is a tendency to underestimate in most of the stations, mainly in Asia $\left(\mathrm{MB}=-163.27 \mathrm{mg} \mathrm{N} \mathrm{m}^{-2}\right.$ ) and Europe ( $\mathrm{MB}=-200.70 \mathrm{mg} \mathrm{N} \mathrm{m}^{-2}$ ). We note that these observations include particulate nitrate in addition to $\mathrm{HNO}_{3}$, and our model omitted nitrate in this study. Therefore, while the underestimation may be partly due to this omission, it is consistent with the higher values of $\mathrm{HNO}_{3}$ observed in the lower and middle troposphere.

Seasonal averages of vertical tropospheric columns (VTCs) of $\mathrm{NO}_{2}$ are compared with SCIAMACHY satellite data in Fig. 10. The model is in line with the observations, capturing the high $\mathrm{NO}_{2}$ values over the most polluted regions, such as Europe, the US and eastern Asia. The phase in the seasonal cycle of the $\mathrm{NO}_{2}$ columns is captured satisfactorily by the model. Throughout the year, the model tends to underestimate $\mathrm{NO}_{2}$ VTCs in megacities, especially during the colder months, and overestimate them in rural regions. The largest discrepancies are seen in eastern China, which suggests an underestimation of emissions regionally. The biomass burning cycle is captured remarkably well, with higher $\mathrm{NO}_{2}$ VTCs in central Africa during DJF and in South America in JJA. The model does really well over the ocean, where only small biases are detected $\left( \pm 0.5 \times 10^{15}\right.$ molec cm $\left.^{-2}\right)$.

\subsection{Ozone $\left(\mathrm{O}_{3}\right)$}

Tropospheric $\mathrm{O}_{3}$ is originated from in situ photochemical production and stratospheric intrusions. Its photochemical production involves the oxidation of $\mathrm{CO}$ and hydrocarbons in the presence of $\mathrm{NO}_{x}$ and sunlight. In remote areas, $\mathrm{CO}$ and $\mathrm{CH}_{4}$ are the most important species oxidized during $\mathrm{O}_{3}$ formation. In polluted areas, short-lived NMVOCs (e.g., HCHO) are present in high concentra- 
Table 7. Annual mean burden, dry deposition of tropospheric $\mathrm{O}_{3}$ and stratospheric inflow $\left(\mathrm{Tg} \mathrm{O}_{3}\right)$ for the NMMB-MONARCH, MOZART-2, TM5, LMDz-INCA, GFDL AM3, and C-IFS global models, and two different multi-model ensembles (including 25 and 15 global models each).

\begin{tabular}{|c|c|c|c|c|c|c|c|c|c|}
\hline \multirow[b]{2}{*}{ Model } & \multicolumn{6}{|c|}{ Burden } & \multirow[b]{2}{*}{ Dry depo. } & \multirow[b]{2}{*}{ Stratos. inflow } & \multirow[b]{2}{*}{ Reference } \\
\hline & Global & $\mathrm{NH}$ & $\mathrm{SH}$ & Trop. & N. extra. & S. extra. & & & \\
\hline NMMB-MONARCH & 348 & 189 & 158 & 171 & 101 & 75 & 1201 & 384 & This study \\
\hline MOZART-2 & 362 & 203 & 159 & 203 & 99 & 60 & 857 & 343 & Horowitz et al. (2003) \\
\hline TM5 & 312 & - & - & 165 & 84 & 63 & 829 & 421 & Huijnen et al. (2010) \\
\hline LMDz-INCA & 303 & 178 & 125 & - & - & - & 1261 & 715 & Folberth et al. (2006) \\
\hline GFDL AM3 & $360 \pm 7$ & - & - & - & - & - & $1205 \pm 20$ & - & Naik et al. (2013a) \\
\hline C-IFS & 390 & - & - & - & - & - & - & - & Flemming et al. (2015) \\
\hline Multi-model & $344 \pm 39$ & - & - & - & - & - & $1003 \pm 200$ & $552 \pm 168$ & Stevenson et al. (2006) \\
\hline Multi-model & $337 \pm 23$ & - & - & - & - & - & - & - & Young et al. (2013) \\
\hline
\end{tabular}

tions and are the most important species. The simulated global burden of tropospheric $\mathrm{O}_{3}$ is shown in Table 7. $\mathrm{O}_{3}$ chemical sources and sinks are dominated by the tropics $\left(171.60 \mathrm{Tg} \mathrm{O}_{3}\right)$. Lower values are predicted in the northern extratropics $\left(101.56 \mathrm{Tg} \mathrm{O}_{3}\right)$ and especially in the southern extratropics $\left(75.41 \mathrm{Tg} \mathrm{O}_{3}\right.$ ), where the presence of precursors is limited. Similar results are found in other global models such as MOZART-2 (Horowitz et al., 2003) and TM5 (Huijnen et al., 2010), with MOZART-2 having a higher and TM5 a lower global burden than our model, and both a lower burden in the southern extratropics (by $10-14 \mathrm{Tg} \mathrm{O}_{3}$ ). Higher $\mathrm{CO}$ concentrations in the $\mathrm{SH}$ (see Table 6) might lead to excessive production of $\mathrm{O}_{3}$ in this region. Our global tropospheric $\mathrm{O}_{3}$ burden $\left(348 \mathrm{Tg} \mathrm{O}_{3}\right)$ is also in good agreement with the C-IFS global model (Flemming et al., 2015), the GFDL AM3 chemistry-climate model (Naik et al., 2013a) and multi-model means (Stevenson et al., 2006; Young et al., 2013).

According to our calculations, $1201 \mathrm{Tg} \mathrm{O}_{3}$ are removed from the troposphere by dry deposition, a value well above TM5 $\left(829 \mathrm{Tg} \mathrm{O}_{3}\right)$ and MOZART-2 $\left(857 \mathrm{Tg} \mathrm{O}_{3}\right)$ estimates, but in agreement with LMDz-INCA $\left(1261 \mathrm{Tg} \mathrm{O}_{3}\right)$, GFDL AM3 $(1205 \pm 20)$ and the multi-model ensemble study by Stevenson et al. (2006) $\left(1003 \pm 200 \mathrm{Tg} \mathrm{O}_{3}\right)$. The net stratospheric input, stratosphere-troposphere exchange (STE), annual rate of the model $\left(384 \mathrm{Tg} \mathrm{O}_{3}\right)$ is also shown in Table 7. STE exchange flux is calculated as the annual balance of the ozone mass crossing the $100 \mathrm{hPa}$ height. The model's STE is in good agreement with other modeling studies, especially with the multi-model ensemble in Stevenson et al. (2006) $\left(552 \pm 168 \mathrm{Tg} \mathrm{O}_{3}\right)$.

Figure 11 shows the time series of $\mathrm{O}_{3}$ daily mean concentration averaged over all available monitoring sites (from top to bottom, WDCGG, CASTNET, EMEP and EANET) over the entire simulation period. The solid red line and solid black line represent the average of observations and the model, respectively. Bars show the 25th-75th quartile interval of all observations (orange) and model simulation (gray). There is an overall good performance, although there is significant positive bias from May to October in the US and Japan. The modeled seasonal cycle agrees well with the observations, showing the highest concentrations during July-August and the lowest ones during NovemberDecember. Although the model captures the seasonal variability, it shows a tendency to overestimate concentrations during the warmer months, i.e., May-September. This positive bias is significantly higher in the US, where the overestimation occurs throughout the year (5-15 ppb). Over Europe, the overestimation during summer is lower than in other regions. Over eastern Asia the model captures reasonably well the peaks in April and May, although it is positively biased during the rest of the year, overestimating during the cold months in contrast to Europe where the model agrees with the observations. Overall the observational networks show a reduction of $\mathrm{O}_{3}$ from May to June, but the model has a tendency to simulate an annual cycle with higher concentrations until July. Possible reasons for the overestimation could be the reduction of the ozone titration due to an excessive emission injection height prescribed in the model, or the drydeposition processes included in our model. Val Martin et al. (2014) show that accurate dry-deposition processes can reduce the summertime surface $\mathrm{O}_{3}$ bias from 30 to $14 \mathrm{ppb}$ and from 13 to $5 \mathrm{ppb}$ over the eastern US and Europe, respectively. Further investigation is required to understand model behavior during this period.

Figure 12 displays the spatial statistics for $\mathrm{O}_{3}$ over all in situ monitoring sites using daily mean data. Areas without emissions such as the South Pole and isolated islands in the tropics show small mean biases and root mean square errors, and good correlations $(>0.80)$. In polluted areas, a good performance is observed in the US midlands and parts of central and southern Europe $(0.60<r<0.80$ and RMSE $<12 \mathrm{ppb})$. Large errors are seen in the northwestern and southern US and northern Europe. Although large errors are seen in all the stations over Japan, the two more distant stations from the main island show high correlation $(r>0.7)$.

In order to assess the vertical distribution of $\mathrm{O}_{3}$, the model results are compared with available ozonesondes in Figs. 13 

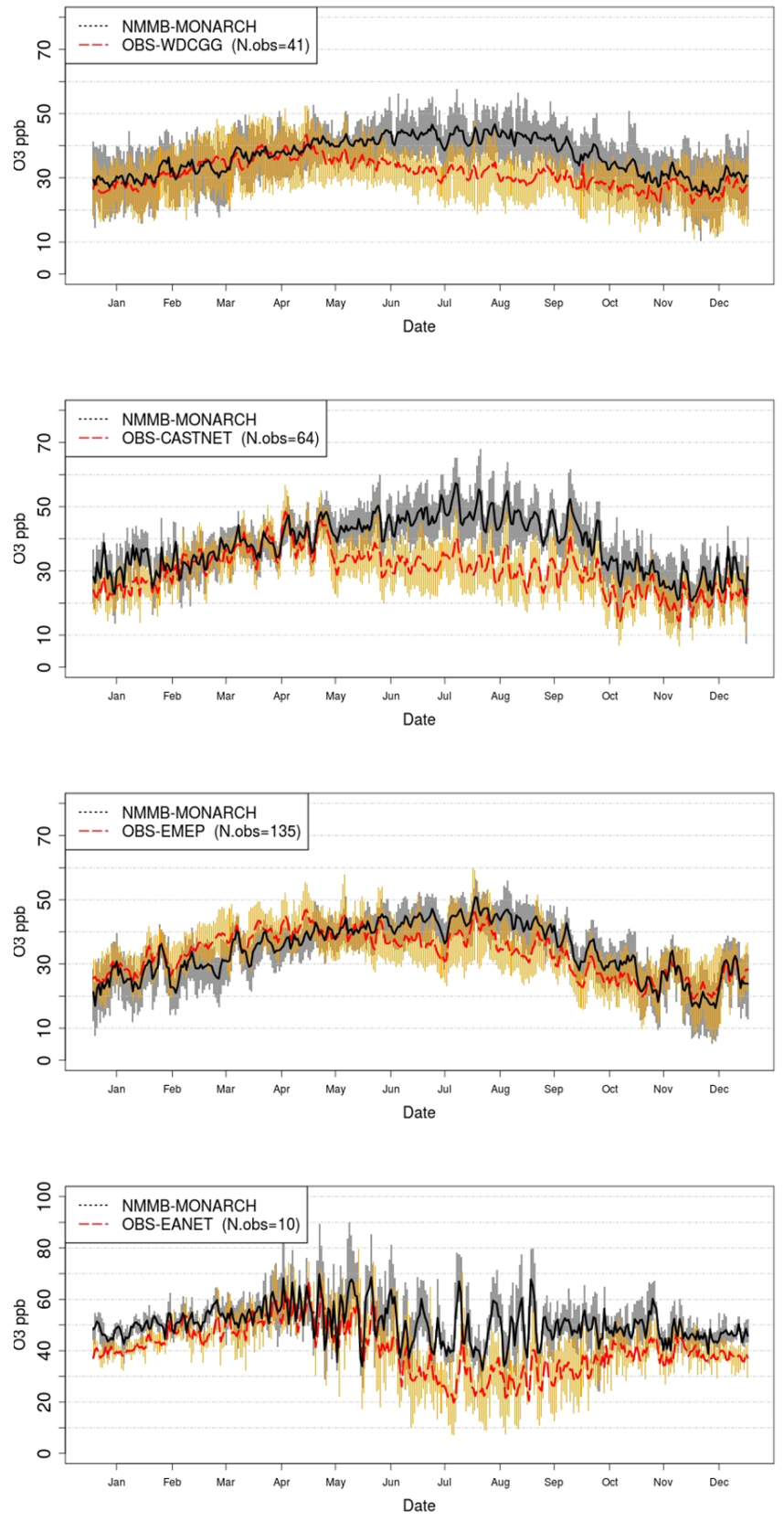

Figure 11. Time series of $\mathrm{O}_{3}$ daily mean concentration averaged over rural WDCGG, CASTNET, EMEP and EANET stations (from top to bottom) in ppb. Observations are depicted with a solid red line and model data with a solid black line. Bars indicate the 25th-75th quartile interval for observations (orange bars) and model (gray bars).

and S7 during the study period (see Table 3 and Fig. 1 for more details). The figures show (from top to bottom) four panels: DJF, MAM, JJA and SON for each region. Measurements are represented by the solid red line and the model results by the solid black line. The variability of the data is shown in the form of standard deviation for both the model and the observations. The magnitude and vertical profile are consistent with the observations. However, the model shows a positive bias of $\sim 5-20 \mathrm{ppb}$ along the troposphere in most of the regions throughout the year. As shown in Sect. 5.2 there is a significant overestimation of $\mathrm{CO}$, especially in the free troposphere for some regions, which may account for the positive $\mathrm{O}_{3}$ biases, although the $\mathrm{CO}$ overestimation mostly occurs in the tropics where $\mathrm{O}_{3}$ biases are not so large. Another reason for this result could be that anthropogenic aerosols and secondary aerosol formation are neglected in this simulation, leading to a higher $\mathrm{O}_{3}$ formation in regions with more precursors. However, this should have more localized effects and therefore it cannot fully explain the biases throughout the troposphere. Possible biases in the stratospheric $\mathrm{O}_{3}$ or the lack of other specific chemistry (e.g., halogen chemistry) could also contribute to this positive bias.

The vertical profile is in good agreement with the observations, with $\mathrm{O}_{3}$ increasing from the lower to higher tropospheric layers. In the lower-middle troposphere the model overestimates $\mathrm{O}_{3}$ in regions with high emissions (Japan, Canada, the US and western Europe), a feature that stands out in DJF $(<20 \mathrm{ppb})$. In western Europe and the US, this bias is reduced at the surface level. In tropical areas (Equator, $\mathrm{NH}$ tropical and western Pacific) the model captures well the observed concentration and vertical structure of $\mathrm{O}_{3}$ in the lower to middle troposphere. However, the model tends to overestimate the $\mathrm{O}_{3}$ in the vicinity of the tropopause layer in these regions (10-20 ppb). At polar regions ( $\mathrm{NH}$ and $\mathrm{SH}$ Polar) the model also presents a tendency to overestimate the vertical structure of $\mathrm{O}_{3} . \mathrm{O}_{3}$ in the tropopause layer is underestimated in the $\mathrm{NH}$ Polar case and overestimated in the $\mathrm{SH}$ Polar case.

Finally, statistics were computed to identify those areas where the errors are more important. Figure 14 shows the mean $\mathrm{O}_{3}$ bias (left), correlation (middle) and RMSE (right) of the model with respect to ozonesondes (data are averaged between 400 and $1000 \mathrm{hPa}$ ). As we have shown, the mean bias is positive for most stations ( $\mathrm{MB}<30 \mathrm{ppb}$ ). Large RMSEs are seen in northern high latitudes $(<50 \mathrm{ppb})$ and in two stations from the US. Europe and Japan present an RMSE around $30 \mathrm{ppb}$ and the tropics and subtropics are regions with lower errors, i.e., RMSE below $30 \mathrm{ppb}$. The highest correlations are seen in polar regions.

\section{Conclusions}

We provided a comprehensive description and evaluation of the gas-phase chemistry component of the NMMBMONARCH model version 1.0 at global scale. The model considers 51 chemical species, solves 156 reactions, and simulates the global distributions of ozone and its precursors, including $\mathrm{CO}, \mathrm{NO}_{x}$, and VOCs. The simulation presented here was configured with a horizontal resolution of $1.4^{\circ} \times 1^{\circ}, 64$ vertical layers and a top of the atmosphere at 

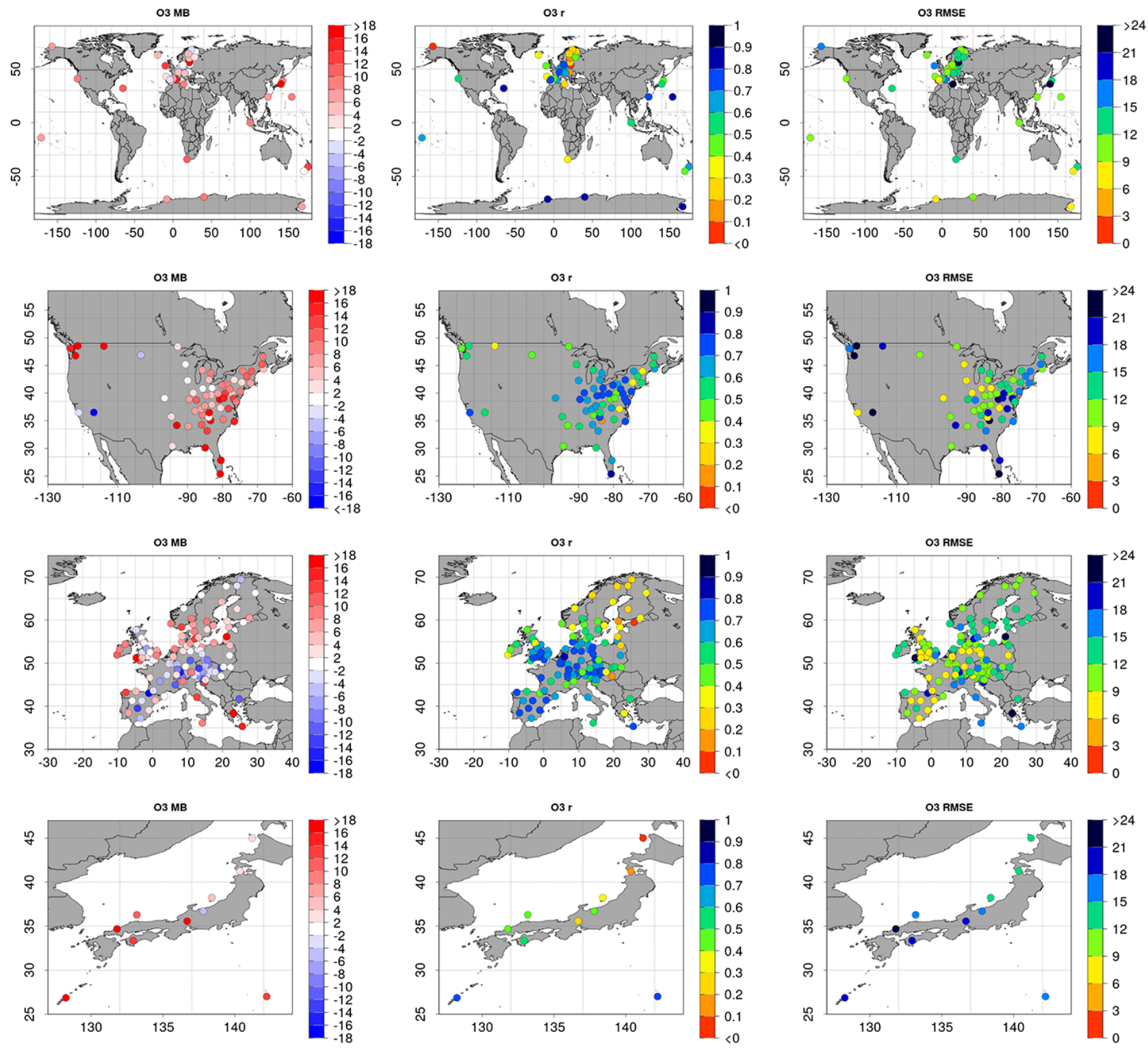

Figure 12. Spatial distribution of the $\mathrm{O}_{3}$ mean bias (MB, ppb) (left panel), correlation ( $r$ ) (middle panel) and RMSE (ppb) (right panel) at rural WDCGG, CASTNET, EMEP and EANET stations (from top to bottom).

$1 \mathrm{hPa}$. Modeled tropospheric ozone and related tracers were evaluated for year 2004 using data from surface-monitoring stations, ozonesondes, satellite and aircraft campaigns. We used emissions from ACCMIP (Lamarque et al., 2010) for fossil fuel combustion, biofuel, biomass burning, soil and oceanic emissions. Biogenic emissions are calculated online with the MEGANv2.04 model (Guenther et al., 2006). We note that in this contribution, we omitted aerosols and lightning emissions; anthropogenic emissions disregard seasonality; and biomass burning emissions are not specific to 2004.

The evaluation of $\mathrm{OH}$ concentrations is in agreement with previous studies (Spivakovsky et al., 2000; Voulgarakis et al., 2013). The $\mathrm{OH}$ peak concentrations occurring in April and
July at northern latitudes are slightly higher than the climatological mean calculated in Spivakovsky et al. (2000). Neglecting anthropogenic aerosols and secondary aerosol formation may be leading to a more oxidized atmosphere due to higher photolysis rates. However, overall, the widespread positive ozone biases identified seem to be responsible for the higher $\mathrm{OH}$ concentrations.

The global annual mean burden of CO (399 Tg) is higher than in other studies, with larger concentrations located in the tropics $(229.43 \mathrm{Tg} \mathrm{CO})$. The model is in relatively good agreement with $\mathrm{CO}$ observations at the surface (daily correlations between 0.3 and 0.7), and shows negative biases at stations over Europe and Japan, and positive biases in Canada 

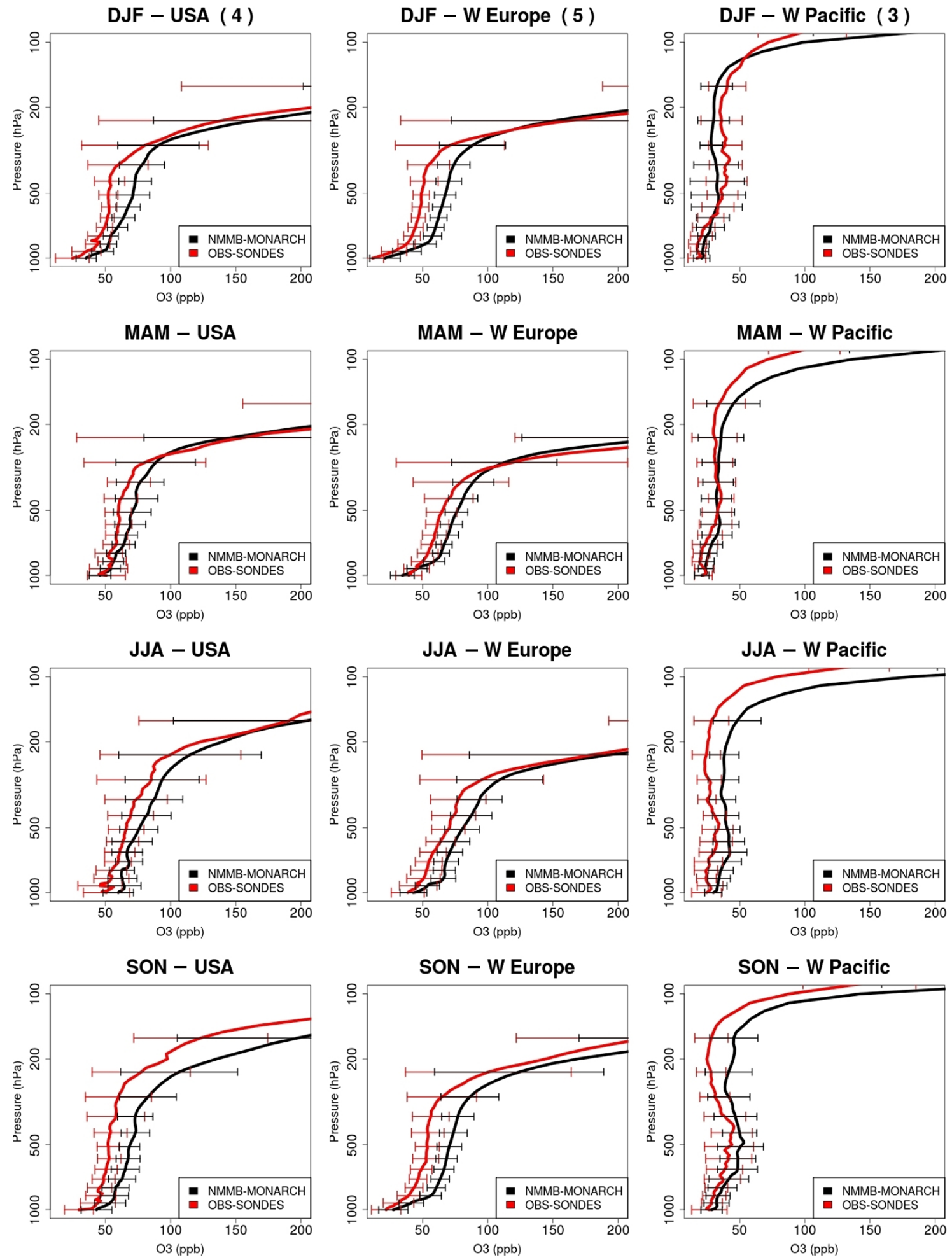

Figure 13. Comparison of ozonesonde measurements (red lines) and simulated (black lines) seasonal vertical profiles of $\mathrm{O}_{3}$ (ppb) and standard deviations (horizontal lines). The region name and the number of stations are given above each plot between brackets. 

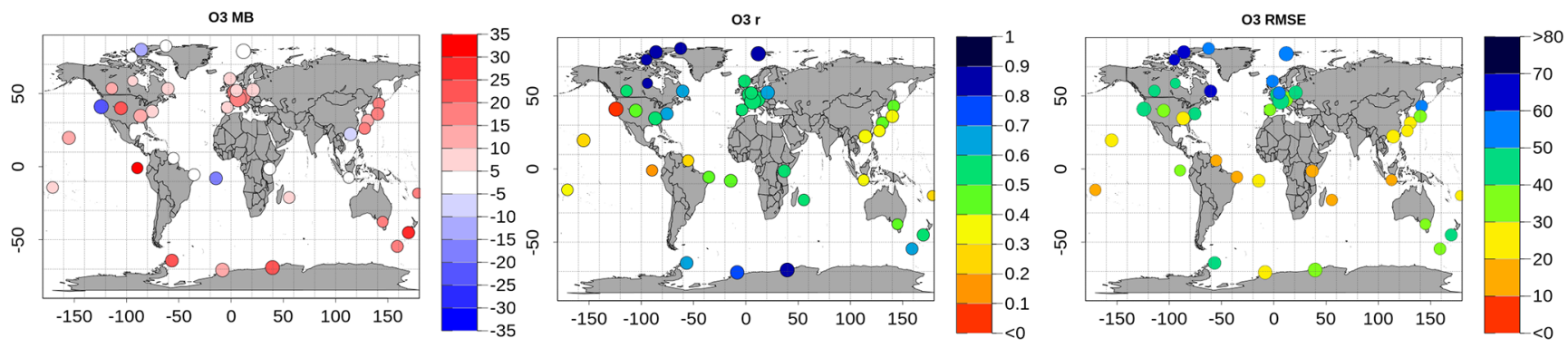

Figure 14. Mean tropospheric ozone bias spatial distribution (MB, ppb) (left panel), correlation (middle panel) and RMSE (ppb) (right panel) for year 2004, averaged between 400 and $1000 \mathrm{hPa}$. The diameter of the circles indicates the number of profiles over the respective stations. The bias is calculated as model minus observation.

and Africa. The largest correlations are found in northern Europe, southern Africa and eastern Asia. Concerning the vertical structure of $\mathrm{CO}$, the model presents a good performance during the DJF and MAM, while positive biases are seen during JJA in most stations. In general, the model overestimates CO from the middle to the upper troposphere throughout the year. Significant underestimation of $\mathrm{CO}$ is seen in Beijing below $600 \mathrm{hPa}$, a common result in other studies which strongly suggests an underestimation of anthropogenic emissions in China. The phase and amplitude of the seasonal cycles of $\mathrm{CO}$ at 800 and $500 \mathrm{hPa}$ in NMMB-MONARCH and MOPITT are quite similar.

Overestimations of $\mathrm{CO}$ are mainly located over westerncentral Africa, western South America, Indonesia and the surrounding Pacific and Indian oceans during the dry season. At $800 \mathrm{hPa}$, a significant negative bias is observed at northern latitudes during winter. These results are most likely related to errors in anthropogenic and biomass burning emission inventories, where the magnitude and the location of the emission are not correctly represented.

Nitrogen oxide abundances are well simulated in almost all locations. Looking at the annual time series of $\mathrm{NO}_{2}$ in Europe, the model captures the higher peaks during winter, although a positive bias is observed during summer. Nitrogen compounds are more sensitive to errors in emissions than other pollutants. We note that the emission inventory neglects seasonal variations for land-based anthropogenic emissions, and therefore we do not account for the potential reduction of $\mathrm{NO}_{x}$ emissions during summer. Over Asia, there is a negative bias of $\mathrm{NO}_{x}$ from March to August, probably due to underestimated emissions in this area. Vertical profiles of $\mathrm{NO}_{x}$ are really well captured by the model, although there is some underestimation in the upper troposphere, possibly due to the lack of lightning $\mathrm{NO}_{x}$ emissions. Vertical profiles of PAN and $\mathrm{HNO}_{3}$ were also compared with observations. Some agreement is seen in these vertical profiles, although the model has a tendency to overestimate. $\mathrm{HNO}_{3}$ wet deposition fluxes tend to be underestimated, and are better captured in the US compared to Europe and Asia.
The comparison with observed $\mathrm{NO}_{2}$ VTC from SCIAMACHY shows that the model reproduces the seasonality and the spatial variability reasonably well, capturing higher $\mathrm{NO}_{2}$ over the most polluted regions. However, the results show a tendency to underestimate $\mathrm{NO}_{2}$ VTC in megacities, especially during DJF and SON, possibly due to a negative bias in the $\mathrm{NO}_{x}$ emissions. The biomass burning cycle is well captured by the model with higher $\mathrm{NO}_{2}$ VTC in central Africa during DJF and in South America during JJA.

The ozone burden $\left(348 \mathrm{Tg} \mathrm{O}_{3}\right)$ is in good agreement with other estimates from state-of-the-art global atmospheric chemistry models. The ozone burden in the southern extratropics is higher in our model, suggesting that higher $\mathrm{CO}$ concentrations in the SH could lead to excessive production of ozone in this area. It seems unlikely that the positive ozone biases are caused by too much STE. STE $\left(384 \mathrm{Tg} \mathrm{O}_{3}\right)$ is consistent with other evaluation studies. In addition, STE has stronger effects in the upper troposphere. Therefore, biases should increase with height, which is not the case in our simulations.

The surface $\mathrm{O}_{3}$ results show a reasonable agreement with the observations, with significant positive biases $(\sim 15 \mathrm{ppb})$ from May to October in the regions of the US and Japan. Surface $\mathrm{O}_{3}$ concentrations are very sensitive to the emissions; consequently, the variability of ozone concentrations can be enhanced by improving the spatio-temporal distribution of the ozone precursor emissions.

The model captures the spatial and seasonal variation of background tropospheric $\mathrm{O}_{3}$ profiles with a positive bias of $\sim 5-20 \mathrm{ppb}$ throughout the troposphere in most of the regions. The positive bias may be due to the significant overestimation of $\mathrm{CO}$, especially in the free troposphere, potential biases in stratospheric $\mathrm{O}_{3}$ or the lack of halogen and aerosol chemistry.

In summary, the NMMB-MONARCH provides a good overall simulation of the main species involved in tropospheric chemistry, although with some caveats that we have highlighted here. Future versions of the model will address problems identified in this study and will include the effect of aerosols in the system. 


\section{Code and data availability}

Copies of the code and data used in this study are readily available upon request from the corresponding authors.

\section{The Supplement related to this article is available online at doi:10.5194/gmd-10-609-2017-supplement.}

Competing interests. The authors declare that they have no conflict of interest.

Acknowledgements. The authors wish to thank WOUDC, GAW, EMEP, WDCGG, CASTNET-EPA, NADP and EANET for the provision of measurement stations. The authors acknowledge for the strong support of the European Commission, Airbus, and the Airlines (Lufthansa, Austrian, Air France) who carry free of charge the MOZAIC equipment and perform the maintenance since 1994. MOZAIC is presently funded by INSU-CNRS (France), Meteo-France, and Forschungszentrum (FZJ, Julich, Germany). The MOZAIC database is supported by ETHER (CNES and INSU-CNRS). Also, thanks go to the free use of the MOPITT CO data obtained from the NASA Langley Research Center Atmospheric Science Data Center. SCIAMACHY radiances have been provided by ESA. We also thank Beatriz Monge-Sanz for providing the COPCAT coefficients. This work is funded by grants CGL2013-46736-R, Supercomputación and e-ciencia Project (CSD2007-0050) from the Consolider-Ingenio 2010 program of the Spanish Ministry of Economy and Competitiveness. Further support was provided by the SEV-2011-00067 grant of the Severo Ochoa Program, awarded by the Spanish Government. Andreas Hilboll received funding from the Earth System Science Research School (ESSReS), an initiative of the Helmholtz Association of German research centres (HGF) at the Alfred Wegener Institute for Polar and Marine Research. Carlos Pérez García-Pando acknowledges long-term support from the AXA Research Fund. The authors thankfully acknowledge the computer resources at MareNostrum and the technical support provided by Barcelona Supercomputing Center (RES-AECT-2015-1-0007). Comments from two anonymous reviewers are gratefully acknowledge.

Edited by: G. A. Folberth

Reviewed by: two anonymous referees

\section{References}

Akimoto, H.: Global air quality and pollution, Science, 302, 17161719,2003

Arakawa, A.: Computational design for long-term numerical integration of the equations of fluid motion: Two-dimensional incompressible flow, Part I, J. Comput. Phys., 1, 119-143, doi:10.1016/0021-9991(66)90015-5, 1966.
Ashworth, K., Wild, O., and Hewitt, C. N.: Sensitivity of isoprene emissions estimated using MEGAN to the time resolution of input climate data, Atmos. Chem. Phys., 10, 1193-1201, doi:10.5194/acp-10-1193-2010, 2010.

Atkinson, R., Baulch, D. L., Cox, R. A., Crowley, J. N., Hampson, R. F., Hynes, R. G., Jenkin, M. E., Rossi, M. J., and Troe, J.: Evaluated kinetic and photochemical data for atmospheric chemistry: Volume $\mathrm{I}-$ gas phase reactions of $\mathrm{O}_{x}, \mathrm{HO}_{x}, \mathrm{NO}_{x}$ and $\mathrm{SO}_{x}$ species, Atmos. Chem. Phys., 4, 1461-1738, doi:10.5194/acp-41461-2004, 2004

Atlas, E. L., Ridley, B. A., and Cantrell, C. A.: The Tropospheric Ozone Production about the Spring Equinox (TOPSE) Experiment: Introduction, J. Geophys. Res.-Atmos., 108, 8353, doi:10.1029/2002JD003172, 2003.

Badia, A. and Jorba, O.: Gas-phase evaluation of the online NMMB/BSC-CTM model over Europe for 2010 in the framework of the AQMEII-Phase2 project, Atmos. Environ., 115, 657 669, doi:10.1016/j.atmosenv.2014.05.055, 2014.

Baklanov, A., Schlünzen, K., Suppan, P., Baldasano, J., Brunner, D., Aksoyoglu, S., Carmichael, G., Douros, J., Flemming, J., Forkel, R., Galmarini, S., Gauss, M., Grell, G., Hirtl, M., Joffre, S., Jorba, O., Kaas, E., Kaasik, M., Kallos, G., Kong, X., Korsholm, U., Kurganskiy, A., Kushta, J., Lohmann, U., Mahura, A., Manders-Groot, A., Maurizi, A., Moussiopoulos, N., Rao, S. T., Savage, N., Seigneur, C., Sokhi, R. S., Solazzo, E., Solomos, S., Sørensen, B., Tsegas, G., Vignati, E., Vogel, B., and Zhang, Y.: Online coupled regional meteorology chemistry models in Europe: current status and prospects, Atmos. Chem. Phys., 14, 317-398, doi:10.5194/acp-14-317-2014, 2014.

Bergamaschi, P., Hein, R., Heimann, M., and Crutzen, P. J.: Inverse modeling of the global $\mathrm{CO}$ cycle: 1 . Inversion of CO mixing ratios, J. Geophys. Res.-Atmos., 105, 1909-1927, doi:10.1029/1999JD900818, 2000.

Betts, A. K.: A new convective adjustment scheme, Part I: Observational and theoretical basis, Q. J. Roy. Meteor. Soc., 112, 677691, doi:10.1002/qj.49711247307, 1986.

Betts, A. K. and Miller, M. J.: A new convective adjustment scheme, Part II: Single column tests using GATE wave, BOMEX, ATEX and arctic air-mass data sets, Q. J. Roy. Meteor. Soc., 112, 693709, doi:10.1002/qj.49711247308, 1986.

Bey, I., Jacob, D. J., Yantosca, R. M., Logan, J. A., Field, B. D., Fiore, A. M., Li, Q., Liu, H. Y., Mickley, L. J., and Schultz, M. G.: Global modeling of tropospheric chemistry with assimilated meteorology: Model description and evaluation, J. Geophys. Res.-Atmos., 106, 23073-23095, doi:10.1029/2001JD000807, 2001.

Bian, H., Prather, M. J., and Takemura, T.: Tropospheric aerosol impacts on trace gas budgets through photolysis, J. Geophys. Res.Atmos., 108, 4242, doi:10.1029/2002JD002743, 2003.

Boersma, K. F., Eskes, H. J., and Brinksma, E. J.: Error analysis for tropospheric $\mathrm{NO}_{2}$ retrieval from space, J. Geophys. Res.-Atmos., 109, D04311, doi:10.1029/2003JD003962, 2004.

Byun, D.: Fundamentals of one-atmosphere dynamics for multiscale Air Quality Modeling, Tech. rep., EPA/600/R-99/030, 1990.

Byun, D. and Ching, J.: Science algorithms of the EPA Models3 community multiscale air quality (CMAQ) modeling system, Rep. EPA/600/R-99/030, 1999. 
Cammas, J.-P., Brioude, J., Chaboureau, J.-P., Duron, J., Mari, C., Mascart, P., Nédélec, P., Smit, H., Pätz, H.-W., Volz-Thomas, A., Stohl, A., and Fromm, M.: Injection in the lower stratosphere of biomass fire emissions followed by long-range transport: a MOZAIC case study, Atmos. Chem. Phys., 9, 5829-5846, doi:10.5194/acp-9-5829-2009, 2009.

Cariolle, D. and Déqué, M.: Southern hemisphere medium-scale waves and total ozone disturbances in a spectral general circulation model, J. Geophys. Res.-Atmos., 91, 10825-10846, doi:10.1029/JD091iD10p10825, 1986.

Chang, J. S., Brost, R. A., Isaksen, I. S. A., Madronich, S., Middleton, P., Stockwell, W. R., and Walcek, C. J.: A threedimensional Eulerian acid deposition model: Physical concepts and formulation, J. Geophys. Res.-Atmos., 92, 14681-14700, doi:10.1029/JD092iD12p14681, 1987.

Chipperfield, M. P.: New version of the TOMCAT/SLIMCAT offline chemical transport model: Intercomparison of stratospheric tracer experiments, Q. J. Roy. Meteor. Soc., 132, 1179-1203, doi:10.1256/qj.05.51, 2006.

Crutzen, P. J.: Photochemical reactions initiated by and influencing ozone in unpolluted tropospheric air, Tellus, 26, 47-57, doi:10.1111/j.2153-3490.1974.tb01951.x, 1974.

Damian, V., Sandu, A., Damian, M., Potra, F., and Carmichael, G. R.: The kinetic preprocessor KPP-a software environment for solving chemical kinetics, Comput. Chem. Eng., 26, 1567-1579, doi:10.1016/S0098-1354(02)00128-X, 2002.

Deeter, M. N., Edwards, D. P., Gille, J. C., Emmons, L. K., Francis, G., Ho, S.-P., Mao, D., Masters, D., Worden, H., Drummond, J. R., and Novelli, P. C.: The MOPITT version $4 \mathrm{CO}$ product: Algorithm enhancements, validation, and long-term stability, J. Geophys. Res.-Atmos., 115, D07306, doi:10.1029/2009JD013005, 2010.

Deeter, M. N., Martinez-Alonso, S., Edwards, D. P., Emmons, L. K., Gille, J. C., Worden, H. M., Pittman, J. V., Daube, B. C., and Wofsy, S. C.: Validation of MOPITT Version 5 thermal-infrared, near-infrared, and multispectral carbon monoxide profile retrievals for 2000-2011, J. Geophys. Res.-Atmos., 118, 67106725, doi:10.1002/jgrd.50272, 2013.

Derwent, R., Jenkin, M., and Saunders, S.: Photochemical ozone creation potentials for a large number of reactive hydrocarbons under European conditions, Atmos. Environ., 30, 181-199, doi:10.1016/1352-2310(95)00303-G, 1996.

Ek, M. B., Mitchell, K. E., Lin, Y., Rogers, E., Grunmann, P., Koren, V., Gayno, G., and Tarpley, J. D.: Implementation of Noah land surface model advances in the National Centers for Environmental Prediction operational mesoscale Eta model, J. Geophys. Res.-Atmos., 108, 8851, doi:10.1029/2002JD003296, 2003.

Elguindi, N., Clark, H., Ordóñez, C., Thouret, V., Flemming, J., Stein, O., Huijnen, V., Moinat, P., Inness, A., Peuch, V.-H., Stohl, A., Turquety, S., Athier, G., Cammas, J.-P., and Schultz, M.: Current status of the ability of the GEMS/MACC models to reproduce the tropospheric $\mathrm{CO}$ vertical distribution as measured by MOZAIC, Geosci. Model Dev., 3, 501-518, doi:10.5194/gmd-3501-2010, 2010.

Emmons, L. K., Hauglustaine, D. A., Müller, J.-F., Carroll, M. A., Brasseur, G. P., Brunner, D., Staehelin, J., Thouret, V., and Marenco, A.: Data composites of airborne observations of tropospheric ozone and its precursors, J. Geophys. Res.-Atmos., 105, 20497-20538, doi:10.1029/2000JD900232, 2000.
Emmons, L. K., Hess, P., Klonecki, A., Tie, X., Horowitz, L., Lamarque, J.-F., Kinnison, D., Brasseur, G., Atlas, E., Browell, E., Cantrell, C., Eisele, F., Mauldin, R. L., Merrill, J., Ridley, B., and Shetter, R.: Budget of tropospheric ozone during TOPSE from two chemical transport models, J. Geophys. Res.-Atmos., 108, 8372, doi:10.1029/2002JD002665, 2003.

Emmons, L. K., Walters, S., Hess, P. G., Lamarque, J.-F., Pfister, G. G., Fillmore, D., Granier, C., Guenther, A., Kinnison, D., Laepple, T., Orlando, J., Tie, X., Tyndall, G., Wiedinmyer, C., Baughcum, S. L., and Kloster, S.: Description and evaluation of the Model for Ozone and Related chemical Tracers, version 4 (MOZART-4), Geosci. Model Dev., 3, 43-67, doi:10.5194/gmd3-43-2010, 2010.

Fast, J. D., Gustafson, W. I., Easter, R. C., Zaveri, R. A., Barnard, J. C., Chapman, E. G., Grell, G. A., and Peckham, S. E.: Evolution of ozone, particulates, and aerosol direct radiative forcing in the vicinity of Houston using a fully coupled meteorology-chemistry-aerosol model, J. Geophys. Res.-Atmos., 111, D21305, doi:10.1029/2005JD006721, 2006.

Fels, S. B. and Schwarzkopf, M. D.: The Simplified Exchange Approximation: A New Method for Radiative Transfer Calculations, J. Atmos. Sci., 32, 1475-1488, doi:10.1175/15200469(1975)032<1475:TSEAAN>2.0.CO;2, 1975.

Ferrier, B. S., Jin, Y., Lin, Y., Black, T., Rogers, E., and DiMego, G.: Implementation of a new grid-scale cloud and precipitation scheme in the NCEP Eta model, paper presented at 15th Conference on Numerical Weather Prediction, B. Am. Meteorol. Soc., San Antonio, Texas, 2002.

Fischer, E. V., Jacob, D. J., Yantosca, R. M., Sulprizio, M. P., Millet, D. B., Mao, J., Paulot, F., Singh, H. B., Roiger, A., Ries, L., Talbot, R. W., Dzepina, K., and Pandey Deolal, S.: Atmospheric peroxyacetyl nitrate (PAN): a global budget and source attribution, Atmos. Chem. Phys., 14, 2679-2698, doi:10.5194/acp-142679-2014, 2014.

Flemming, J., Inness, A., Flentje, H., Huijnen, V., Moinat, P., Schultz, M. G., and Stein, O.: Coupling global chemistry transport models to ECMWF's integrated forecast system, Geosci. Model Dev., 2, 253-265, doi:10.5194/gmd-2-253-2009, 2009.

Flemming, J., Huijnen, V., Arteta, J., Bechtold, P., Beljaars, A., Blechschmidt, A.-M., Diamantakis, M., Engelen, R. J., Gaudel, A., Inness, A., Jones, L., Josse, B., Katragkou, E., Marecal, V., Peuch, V.-H., Richter, A., Schultz, M. G., Stein, O., and Tsikerdekis, A.: Tropospheric chemistry in the Integrated Forecasting System of ECMWF, Geosci. Model Dev., 8, 975-1003, doi:10.5194/gmd-8-975-2015, 2015.

Folberth, G. A., Hauglustaine, D. A., Lathière, J., and Brocheton, F.: Interactive chemistry in the Laboratoire de Météorologie Dynamique general circulation model: model description and impact analysis of biogenic hydrocarbons on tropospheric chemistry, Atmos. Chem. Phys., 6, 2273-2319, doi:10.5194/acp-62273-2006, 2006

Foley, K. M., Roselle, S. J., Appel, K. W., Bhave, P. V., Pleim, J. E., Otte, T. L., Mathur, R., Sarwar, G., Young, J. O., Gilliam, R. C., Nolte, C. G., Kelly, J. T., Gilliland, A. B., and Bash, J. O.: Incremental testing of the Community Multiscale Air Quality (CMAQ) modeling system version 4.7, Geosci. Model Dev., 3, 205-226, doi:10.5194/gmd-3-205-2010, 2010.

Gery, M. W., Whitten, G. Z., Killus, J. P., and Dodge, M. C.: A photochemical kinetics mechanism for urban and regional scale 
computer modeling, J. Geophys. Res.-Atmos., 94, 12925-12956, doi:10.1029/JD094iD10p12925, 1989.

Gong, S. L., Lavoué, D., Zhao, T. L., Huang, P., and Kaminski, J. W.: GEM-AQ/EC, an on-line global multi-scale chemical weather modelling system: model development and evaluation of global aerosol climatology, Atmos. Chem. Phys., 12, 8237-8256, doi:10.5194/acp-12-8237-2012, 2012.

Granier, C., Lamarque, J., Mieville, A., Muller, J., Olivier, J., Orlando, J., Peters, J., Petron, G., Tyndall, G., and Wallens, S.: POET, a database of surface emissions of ozone precursors, available at: http://accent.aero.jussieu.fr/POET_metadata. php (last access: April 2014), 2005.

Guenther, A., Karl, T., Harley, P., Wiedinmyer, C., Palmer, P. I., and Geron, C.: Estimates of global terrestrial isoprene emissions using MEGAN (Model of Emissions of Gases and Aerosols from Nature), Atmos. Chem. Phys., 6, 3181-3210, doi:10.5194/acp-63181-2006, 2006.

Hauglustaine, D. A., Brasseur, G. P., Walters, S., Rasch, P. J., Müller, J.-F., Emmons, L. K., and Carroll, M. A.: MOZART, a global chemical transport model for ozone and related chemical tracers: 2. Model results and evaluation, J. Geophys. Res.Atmos., 103, 28291-28335, doi:10.1029/98JD02398, 1998.

Haustein, K., Pérez, C., Baldasano, J. M., Jorba, O., Basart, S., Miller, R. L., Janjic, Z., Black, T., Nickovic, S., Todd, M. C., Washington, R., Müller, D., Tesche, M., Weinzierl, B., Esselborn, M., and Schladitz, A.: Atmospheric dust modeling from meso to global scales with the online NMMB/BSC-Dust model - Part 2: Experimental campaigns in Northern Africa, Atmos. Chem. Phys., 12, 2933-2958, doi:10.5194/acp-12-2933-2012, 2012.

Hertel, O., Berkowicz, R., and Christensen, J.: Test of two numerical schemes for use in atmospheric transport-chemistry models, Atmos. Environ. A-Gen., 27, 2591-2611, doi:10.1016/09601686(93)90032-T, 1993.

Heue, K.-P., Richter, A., Bruns, M., Burrows, J. P., v. Friedeburg, C., Platt, U., Pundt, I., Wang, P., and Wagner, T.: Validation of SCIAMACHY tropospheric $\mathrm{NO}_{2}$-columns with AMAXDOAS measurements, Atmos. Chem. Phys., 5, 1039-1051, doi:10.5194/acp5-1039-2005, 2005.

Hilboll, A., Richter, A., Rozanov, A., Hodnebrog, Ø., Heckel, A., Solberg, S., Stordal, F., and Burrows, J. P.: Improvements to the retrieval of tropospheric $\mathrm{NO}_{2}$ from satellite - stratospheric correction using SCIAMACHY limb/nadir matching and comparison to Oslo CTM2 simulations, Atmos. Meas. Tech., 6, 565-584, doi:10.5194/amt-6-565-2013, 2013.

Horowitz, L. W., Walters, S., Mauzerall, D. L., Emmons, L. K., Rasch, P. J., Granier, C., Tie, X., Lamarque, J.-F., Schultz, M. G., Tyndall, G. S., Orlando, J. J., and Brasseur, G. P.: A global simulation of tropospheric ozone and related tracers: Description and evaluation of MOZART, version 2, J. Geophys. Res.-Atmos., 108, 4784, doi:10.1029/2002JD002853, 2003.

Hsu, J. and Prather, M. J.: Stratospheric variability and tropospheric ozone, J. Geophys. Res.-Atmos., 114, D06102, doi:10.1029/2008JD010942, 2009.

Huijnen, V., Williams, J., van Weele, M., van Noije, T., Krol, M., Dentener, F., Segers, A., Houweling, S., Peters, W., de Laat, J., Boersma, F., Bergamaschi, P., van Velthoven, P., Le Sager, P., Eskes, H., Alkemade, F., Scheele, R., Nédélec, P., and Pätz, H.-W.: The global chemistry transport model TM5: description and eval- uation of the tropospheric chemistry version 3.0, Geosci. Model Dev., 3, 445-473, doi:10.5194/gmd-3-445-2010, 2010.

Im, U., Bianconi, B., Solazzo, E., Kioutsioukis, I., Badia, A., Balzarini, A., Baró, R., Bellasio, R., Brunner, D., Chemel, C., Curci, G., Flemming, J., Forkel, R., Giordano, L., JiménezGuerrero, P., Hirtl, M., Hodzic, A., Honzak, L., Jorba, O., Knote, C., Kuenen, J., Makar, P., Manders-Groot, A., Neal, L., Pérez, J., Pirovano, G., Pouliot, G. San Jose, R., Savage, N., Schroder, W., Sokhi, R., Syrakov, D., Torian, A., Tuccella, R., Werhahn, J., Wolke, R., Yahya, K., Zabkar, R., Zhang, Y., Zhang, J., Hogrefe, C., and Galmarini, S.: Evaluation of operational online-coupled regional air quality models over Europe and North America in the context of AQMEII phase 2, Part I: Ozone, Atmos. Environ., 115, 421-441, doi:10.1016/j.atmosenv.2014.09.042, 2014.

Jacob, D. J., Crawford, J. H., Kleb, M. M., Connors, V. S., Bendura, R. J., Raper, J. L., Sachse, G. W., Gille, J. C., Emmons, L., and Heald, C. L.: Transport and Chemical Evolution over the Pacific (TRACE-P) aircraft mission: Design, execution, and first results, J. Geophys. Res.-Atmos., 108, 9000, doi:10.1029/2002JD003276, 2003.

Jacobson, M. Z.: GATOR-GCMM: A global- through urban-scale air pollution and weather forecast model: 1 . Model design and treatment of subgrid soil, vegetation, roads, rooftops, water, sea ice, and snow, J. Geophys. Res.-Atmos., 106, 5385-5401, doi:10.1029/2000JD900560, 2001.

Janjic, Z.: Pressure gradient force and advection scheme used for forecasting with steep and small scale topography, Contrib. Atmos. Phys., 50, 186-199, 1977.

Janjic, Z.: Forward-backward scheme modified to prevent twogrid-interval noise and its application in sigma coordinate models, Contrib. Atmos. Phys., 52, 69-84, 1979.

Janjic, Z.: Nonlinear Advection Schemes and Energy Cascade on Semi-Staggered Grids, Mon. Weather Rev., 112, 1234-1245, doi:10.1175/1520-0493(1984)112<1234:NASAEC>2.0.CO;2, 1984.

Janjic, Z.: The step-mountain coordinates: physical package, Mon. Weather Rev., 118, 1429-1443, doi:10.1175/15200493(1990)118<1429:TSMCPP>2.0.CO;2, 1990.

Janjic, Z.: The Step-Mountain Eta Coordinate Model: Further Developments of the Convection, Viscous Sublayer, and Turbulence Closure Schemes, Mon. Weather Rev., 122, 927-945, doi:10.1175/1520-0493(1994)122<0927:TSMECM>2.0.CO;2, 1994.

Janjic, Z.: Comments on Development and Evaluation of a Convection Scheme for Use in Climate Models, J. Atmos. Sci., 57, 3686-3686, 2000.

Janjic, Z.: A nonhydrostatic model based on a new approach, Meteorol. Atmos. Phys., 82, 271-285, 2003.

Janjic, Z.: A unified model approach from meso to global scales, Geophys. Res. Abstracts, 7, 05582, SRef-ID: 16077962/gra/EGU05-A-05582, 2005.

Janjic, Z. and Gall, I.: Scientific documentation of the NCEP nonhydrostatic multiscale model on the $\mathrm{B}$ grid (NMMB), Part 1: Dynamics, Tech. rep., NCAR/TN-489+STR, 75 pp., doi:10.5065/D6WH2MZX, 2012.

Janjic, Z., Gerrity Jr., J., and Nickovic, S.: An alternative approach to nonhydrostatic modeling, Mon. Weather Rev., 129, 11641178, 2001. 
Janjic, Z., Huang, H., and Lu, S.: A unified atmospheric model suitable for studying transport of mineral aerosols from meso to global scales, in: IOP Conference Series: Earth and Environmental Science, IOP Publishing, 7, 012011, 2009.

Jorba, O., Dabdub, D., Blaszczak-Boxe, C., Pérez, C., Janjic, Z., Baldasano, J. M., Spada, M., Badia, A., and Gonçalves, M.: Potential significance of photoexcited $\mathrm{NO}_{2}$ on global air quality with the NMMB/BSC chemical transport model, J. Geophys. Res.-Atmos., 117, D13301, doi:10.1029/2012JD017730, 2012.

Jost, H.-J., Drdla, K., Stohl, A., Pfister, L., Loewenstein, M., Lopez, J. P., Hudson, P. K., Murphy, D. M., Cziczo, D. J., Fromm, M., Bui, T. P., Dean-Day, J., Gerbig, C., Mahoney, M. J., Richard, E. C., Spichtinger, N., Pittman, J. V., Weinstock, E. M., Wilson, J. C., and Xueref, I.: In-situ observations of mid-latitude forest fire plumes deep in the stratosphere, Geophys. Res. Lett., 31, L11101, doi:10.1029/2003GL019253, 2004.

Labrador, L. J., von Kuhlmann, R., and Lawrence, M. G.: Strong sensitivity of the global mean $\mathrm{OH}$ concentration and the tropospheric oxidizing efficiency to the source of $\mathrm{NO}_{x}$ from lightning, Geophys. Res. Lett., 31, L06102, doi:10.1029/2003GL019229, 2004.

Lamarque, J.-F., Bond, T. C., Eyring, V., Granier, C., Heil, A., Klimont, Z., Lee, D., Liousse, C., Mieville, A., Owen, B., Schultz, M. G., Shindell, D., Smith, S. J., Stehfest, E., Van Aardenne, J., Cooper, O. R., Kainuma, M., Mahowald, N., McConnell, J. R., Naik, V., Riahi, K., and van Vuuren, D. P.: Historical (1850-2000) gridded anthropogenic and biomass burning emissions of reactive gases and aerosols: methodology and application, Atmos. Chem. Phys., 10, 7017-7039, doi:10.5194/acp10-7017-2010, 2010.

Lamarque, J.-F., Shindell, D. T., Josse, B., Young, P. J., Cionni, I., Eyring, V., Bergmann, D., Cameron-Smith, P., Collins, W. J., Doherty, R., Dalsoren, S., Faluvegi, G., Folberth, G., Ghan, S. J., Horowitz, L. W., Lee, Y. H., MacKenzie, I. A., Nagashima, T., Naik, V., Plummer, D., Righi, M., Rumbold, S. T., Schulz, M., Skeie, R. B., Stevenson, D. S., Strode, S., Sudo, K., Szopa, S., Voulgarakis, A., and Zeng, G.: The Atmospheric Chemistry and Climate Model Intercomparison Project (ACCMIP): overview and description of models, simulations and climate diagnostics, Geosci. Model Dev., 6, 179-206, doi:10.5194/gmd-6-179-2013, 2013.

Lelieveld, J., Peters, W., Dentener, F. J., and Krol, M. C.: Stability of tropospheric hydroxyl chemistry, J. Geophys. Res.-Atmos., 107, 4715, doi:10.1029/2002JD002272, 2002.

Marais, E. A., Jacob, D. J., Guenther, A., Chance, K., Kurosu, T. P., Murphy, J. G., Reeves, C. E., and Pye, H. O. T.: Improved model of isoprene emissions in Africa using Ozone Monitoring Instrument (OMI) satellite observations of formaldehyde: implications for oxidants and particulate matter, Atmos. Chem. Phys., 14, 7693-7703, doi:10.5194/acp-14-7693-2014, 2014.

Miyazaki, K., Eskes, H. J., and Sudo, K.: Global $\mathrm{NO}_{x}$ emission estimates derived from an assimilation of OMI tropospheric $\mathrm{NO}_{2}$ columns, Atmos. Chem. Phys., 12, 2263-2288, doi:10.5194/acp12-2263-2012, 2012

Mlawer, E. J., Taubman, S. J., Brown, P. D., Iacono, M. J., and Clough, S. A.: Radiative transfer for inhomogeneous atmospheres: RRTM, a validated correlated-k model for the longwave, J. Geophys. Res.-Atmos., 102, 16663-16682, doi:10.1029/97JD00237, 1997.
Monge-Sanz, B. M., Chipperfield, M. P., Cariolle, D., and Feng, W.: Results from a new linear $\mathrm{O}_{3}$ scheme with embedded heterogeneous chemistry compared with the parent full-chemistry 3-D CTM, Atmos. Chem. Phys., 11, 1227-1242, doi:10.5194/acp-111227-2011, 2011.

Monin, A. S. and Obukhov, A. M.: Osnovnye zakonomernosti turbulentnogo peremesivanija $\mathrm{v}$ prizemnom sloe atmosfery, Trudy geofiz. inst. AN SSSR, 24, 163-187, 1954.

Naik, V., Horowitz, L. W., Fiore, A. M., Ginoux, P., Mao, J., Aghedo, A. M., and Levy, H.: Impact of preindustrial to presentday changes in short-lived pollutant emissions on atmospheric composition and climate forcing, J. Geophys. Res.-Atmos., 118, 8086-8110, doi:10.1002/jgrd.50608, 2013a.

Naik, V., Voulgarakis, A., Fiore, A. M., Horowitz, L. W., Lamarque, J.-F., Lin, M., Prather, M. J., Young, P. J., Bergmann, D., Cameron-Smith, P. J., Cionni, I., Collins, W. J., Dalsøren, S. B., Doherty, R., Eyring, V., Faluvegi, G., Folberth, G. A., Josse, B., Lee, Y. H., MacKenzie, I. A., Nagashima, T., van Noije, T. P. C., Plummer, D. A., Righi, M., Rumbold, S. T., Skeie, R., Shindell, D. T., Stevenson, D. S., Strode, S., Sudo, K., Szopa, S., and Zeng, G.: Preindustrial to present-day changes in tropospheric hydroxyl radical and methane lifetime from the Atmospheric Chemistry and Climate Model Intercomparison Project (ACCMIP), Atmos. Chem. Phys., 13, 5277-5298, doi:10.5194/acp-13-5277-2013, 2013b.

Park, R. J., Pickering, K. E., Allen, D. J., Stenchikov, G. L., and Fox-Rabinovitz, M. S.: Global simulation of tropospheric ozone using the University of Maryland Chemical Transport Model (UMD-CTM): 1. Model description and evaluation, J. Geophys. Res.-Atmos., 109, D09301, doi:10.1029/2003JD004266, 2004.

Pérez, C., Haustein, K., Janjic, Z., Jorba, O., Huneeus, N., Baldasano, J. M., Black, T., Basart, S., Nickovic, S., Miller, R. L., Perlwitz, J. P., Schulz, M., and Thomson, M.: Atmospheric dust modeling from meso to global scales with the online NMMB/BSC-Dust model - Part 1: Model description, annual simulations and evaluation, Atmos. Chem. Phys., 11, 1300113027, doi:10.5194/acp-11-13001-2011, 2011.

Petritoli, A., Bonasoni, P., Giovanelli, G., Ravegnani, F., Kostadinov, I., Bortoli, D., Weiss, A., Schaub, D., Richter, A., and Fortezza, F.: First comparison between ground-based and satellite-borne measurements of tropospheric nitrogen dioxide in the Po basin, J. Geophys. Res.-Atmos., 109, D15307, doi:10.1029/2004JD004547, 2004.

Prather, M., Ehhalt, D., and Dentener, F.: Atmospheric chemistry and greenhouse gases in Climate Change 2001, 241-287, 2001.

Prinn, R., Huang, J., Weiss, R., Cunnold, D., Fraser, P., Simmonds, P., McCulloch, A., Harth, C., Salameh, P., O’Doherty, S., Wang, R., Porter, L., and Miller, B.: Evidence for substantial variations of atmospheric hydroxyl radicals in the past two decades, Science, 292, 1882-1888, 2001.

Raper, J. L., Kleb, M. M., Jacob, D. J., Davis, D. D., Newell, R. E., Fuelberg, H. E., Bendura, R. J., Hoell, J. M., and McNeal, R. J.: Pacific Exploratory Mission in the Tropical Pacific: PEM-Tropics B, March-April 1999, J. Geophys. Res.-Atmos., 106, 32401-32425, doi:10.1029/2000JD900833, 2001.

Real, E. and Sartelet, K.: Modeling of photolysis rates over Europe: impact on chemical gaseous species and aerosols, Atmos. Chem. Phys., 11, 1711-1727, doi:10.5194/acp-11-1711-2011, 2011. 
Richter, A., Burrows, J. P., Nüß, H., Granier, C., and Niemeier, U.: Increase in tropospheric nitrogen dioxide over China observed from space, Nature, 437, 129-132, 2005.

Sander, S. P., Golden, D., Kurylo, M., Moortgat, G., Wine, P., Ravishankara, A., Kolb, C., Molina, M., Finlayson-Pitts, B., Huie, R., and Orkin, V. L.: Chemical kinetics and photochemical data for use in atmospheric studies, Evaluation no. 15, JPL Publication No. 06-02, 2006.

Sandu, A. and Sander, R.: Technical note: Simulating chemical systems in Fortran90 and Matlab with the Kinetic PreProcessor KPP-2.1, Atmos. Chem. Phys., 6, 187-195, doi:10.5194/acp-6187-2006, 2006.

Schultz, M. and Rast, S.: Emission datasets and methodologies for estimating emissions, Tech. rep., RETRO Report D16, http://retro-archive.iek.fz-juelich.de/data/documents/reports/ D1-6_final.pdf (last access: April 2014), 2007.

Schumann, U., Schlager, H., Arnold, F., Ovarlez, J., Kelder, H., Hov, O., Hayman, G., Isaksen, I. S. A., Staehelin, J., and Whitefield, P. D.: Pollution from aircraft emissions in the North Atlantic flight corridor: Overview on the POLINAT projects, J. Geophys. Res.-Atmos., 105, 3605-3631, doi:10.1029/1999JD900941, 2000.

Seinfeld, J. and Pandis, S.: Atmospheric Chemistry and Physics, Wiley-Interscience, New York, 1998.

Shindell, D. T., Faluvegi, G., Stevenson, D. S., Krol, M. C., Emmons, L. K., Lamarque, J.-F., Pétron, G., Dentener, F. J., Ellingsen, K., Schultz, M. G., Wild, O., Amann, M., Atherton, C. S., Bergmann, D. J., Bey, I., Butler, T., Cofala, J., Collins, W. J., Derwent, R. G., Doherty, R. M., Drevet, J., Eskes, H. J., Fiore, A. M., Gauss, M., Hauglustaine, D. A., Horowitz, L. W., Isaksen, I. S. A., Lawrence, M. G., Montanaro, V., Müller, J.F., Pitari, G., Prather, M. J., Pyle, J. A., Rast, S., Rodriguez, J. M., Sanderson, M. G., Savage, N. H., Strahan, S. E., Sudo, K., Szopa, S., Unger, N., van Noije, T. P. C., and Zeng, G.: Multimodel simulations of carbon monoxide: Comparison with observations and projected near-future changes, J. Geophys. Res.Atmos., 111, D19306, doi:10.1029/2006JD007100, 2006.

Singh, H. B. and Hanst, P. L.: Peroxyacetyl nitrate (PAN) in the unpolluted atmosphere: An important reservoir for nitrogen oxides, Geophys. Res. Lett., 8, 941-944, doi:10.1029/GL008i008p00941, 1981.

Spada, M., Jorba, O., Pérez García-Pando, C., Janjic, Z., and Baldasano, J. M.: Modeling and evaluation of the global sea-salt aerosol distribution: sensitivity to size-resolved and sea-surface temperature dependent emission schemes, Atmos. Chem. Phys., 13, 11735-11755, doi:10.5194/acp-13-11735-2013, 2013.

Spada, M., Jorba, O., García-Pando, C. P., Janjic, Z., and Baldasano, J.: On the evaluation of global sea-salt aerosol models at coastal/orographic sites, Atmos. Environ., 101, 41-48, doi:10.1016/j.atmosenv.2014.11.019, 2015.

Spada, M., Jorba, O., Pérez García-Pando, C., Tsigaridis, K., Soares, J., and Janjic, Z.: Global aerosols in the online multiscale NMMB-MONARCH, in preparation, 2017.

Spivakovsky, C. M., Logan, J. A., Montzka, S. A., Balkanski, Y. J., Foreman-Fowler, M., Jones, D. B. A., Horowitz, L. W., Fusco, A. C., Brenninkmeijer, C. A. M., Prather, M. J., Wofsy, S. C., and McElroy, M. B.: Three-dimensional climatological distribution of tropospheric $\mathrm{OH}$ : Update and evaluation, J. Geophys. Res.Atmos., 105, 8931-8980, doi:10.1029/1999JD901006, 2000.
Stein, O., Schultz, M. G., Bouarar, I., Clark, H., Huijnen, V., Gaudel, A., George, M., and Clerbaux, C.: On the wintertime low bias of Northern Hemisphere carbon monoxide found in global model simulations, Atmos. Chem. Phys., 14, 9295-9316, doi:10.5194/acp-14-9295-2014, 2014.

Stevenson, D. S., Dentener, F. J., Schultz, M. G., Ellingsen, K., van Noije, T. P. C., Wild, O., Zeng, G., Amann, M., Atherton, C. S., Bell, N., Bergmann, D. J., Bey, I., Butler, T., Cofala, J., Collins, W. J., Derwent, R. G., Doherty, R. M., Drevet, J., Eskes, H. J., Fiore, A. M., Gauss, M., Hauglustaine, D. A., Horowitz, L. W., Isaksen, I. S. A., Krol, M. C., Lamarque, J.-F., Lawrence, M. G., Montanaro, V., Müller, J.-F., Pitari, G., Prather, M. J., Pyle, J. A., Rast, S., Rodriguez, J. M., Sanderson, M. G., Savage, N. H., Shindell, D. T., Strahan, S. E., Sudo, K., and Szopa, S.: Multimodel ensemble simulations of present-day and near-future tropospheric ozone, J. Geophys. Res.-Atmos., 111, D08301, doi:10.1029/2005JD006338, 2006.

Stohl, A., Bonasoni, P., Cristofanelli, P., Collins, W., Feichter, J., Frank, A., Forster, C., Gerasopoulos, E., Gäggeler, H., James, P., Kentarchos, T., Kromp-Kolb, H., Krüger, B., Land, C., Meloen, J., Papayannis, A., Priller, A., Seibert, P., Sprenger, M., Roelofs, G. J., Scheel, H. E., Schnabel, C., Siegmund, P., Tobler, L., Trickl, T., Wernli, H., Wirth, V., Zanis, P., and Zerefos, C.: Stratosphere-troposphere exchange: A review, and what we have learned from STACCATO, J. Geophys. Res.-Atmos., 108, 8516, doi:10.1029/2002JD002490, 2003.

Tang, Y., McQueen, J. T., Lu, S., Black, T. L., Janjic, Z., Iredell, M. D., Pérez García-Pando, C., and Jorba O.: Recent status of NEMS/NMMB-AQ development, paper presented at 8th Annual CMAS Conference, US Environ. Prot. Agency, Chapel Hill, NC, 2009.

Thompson, A. M., Witte, J. C., McPeters, R. D., Oltmans, S. J., Schmidlin, F. J., Logan, J. A., Fujiwara, M., Kirchhoff, V. W. J. H., Posny, F., Coetzee, G. J. R., Hoegger, B., Kawakami, S., Ogawa, T., Johnson, B. J., Vömel, H., and Labow, G.: Southern Hemisphere Additional Ozonesondes (SHADOZ) 1998-2000 tropical ozone climatology 1. Comparison with Total Ozone Mapping Spectrometer (TOMS) and ground-based measurements, J. Geophys. Res.-Atmos., 108, 8238, doi:10.1029/2001JD000967, 2003a.

Thompson, A. M., Witte, J. C., Oltmans, S. J., Schmidlin, F. J., Logan, J. A., Fujiwara, M., Kirchhoff, V. W. J. H., Posny, F., Coetzee, G. J. R., Hoegger, B., Kawakami, S., Ogawa, T., Fortuin, J. P. F., and Kelder, H. M.: Southern Hemisphere Additional Ozonesondes (SHADOZ) 1998-2000 tropical ozone climatology 2. Tropospheric variability and the zonal wave-one, J. Geophys. Res.-Atmos., 108, 8241, doi:10.1029/2002JD002241, 2003 b.

Tie, X., Zhang, R., Brasseur, G., Emmons, L., and Lei, W.: Effects of lightning on reactive nitrogen and nitrogen reservoir species in the troposphere, J. Geophys. Res.-Atmos., 106, 3167-3178, doi:10.1029/2000JD900565, 2001.

Tie, X., Zhang, R., Brasseur, G., and Lei, W.: Global $\mathrm{NO}_{x}$ Production by Lightning, J. Atmos. Chem., 43, 61-74, doi:10.1023/A:1016145719608, 2002.

Tilmes, S., Lamarque, J.-F., Emmons, L. K., Conley, A., Schultz, M. G., Saunois, M., Thouret, V., Thompson, A. M., Oltmans, S. J., Johnson, B., and Tarasick, D.: Technical Note: Ozonesonde climatology between 1995 and 2011: description, 
evaluation and applications, Atmos. Chem. Phys., 12, 74757497, doi:10.5194/acp-12-7475-2012, 2012.

Turquety, S., Clerbaux, C., Law, K., Coheur, P.-F., Cozic, A., Szopa, S., Hauglustaine, D. A., Hadji-Lazaro, J., Gloudemans, A. M. S., Schrijver, H., Boone, C. D., Bernath, P. F., and Edwards, D. P.: $\mathrm{CO}$ emission and export from Asia: an analysis combining complementary satellite measurements (MOPITT, SCIAMACHY and ACE-FTS) with global modeling, Atmos. Chem. Phys., 8, 5187-5204, doi:10.5194/acp-8-5187-2008, 2008.

Val Martin, M., Heald, C. L., and Arnold, S. R.: Coupling dry deposition to vegetation phenology in the Community Earth System Model: Implications for the simulation of surface $\mathrm{O}_{3}$, Geophys. Res. Lett., 41, 2988-2996, doi:10.1002/2014GL059651, 2014.

Van Aardenne, J. A., Dentener, F. J., Olivier, J. G. J., and Peters, J. A. H. W.: The EDGAR 3.2 Fast Track 2000 dataset (32FT2000), Tech. rep., available at: http://themasites.pbl.nl/images/ Description_of_EDGAR_32FT2000(v8)_tcm61-46462.pdf (last access: April 2014), 2005.

Voulgarakis, A., Naik, V., Lamarque, J.-F., Shindell, D. T., Young, P. J., Prather, M. J., Wild, O., Field, R. D., Bergmann, D., CameronSmith, P., Cionni, I., Collins, W. J., Dalsøren, S. B., Doherty, R. M., Eyring, V., Faluvegi, G., Folberth, G. A., Horowitz, L. W., Josse, B., MacKenzie, I. A., Nagashima, T., Plummer, D. A., Righi, M., Rumbold, S. T., Stevenson, D. S., Strode, S. A., Sudo, K., Szopa, S., and Zeng, G.: Analysis of present day and future $\mathrm{OH}$ and methane lifetime in the ACCMIP simulations, Atmos. Chem. Phys., 13, 2563-2587, doi:10.5194/acp-13-25632013, 2013.

Vukovic, A., Rajkovic, B., and Janjic, Z.: Land ice sea surface model: Short description and verification, paper presented at 2010 International Congress on Environmental Modelling and Software Modelling for Environment's Sake, Int. Environ. Model. Softw. Soc., Ottawa, Canada, 2010.

Wesely, M.: Parameterization of surface resistances to gaseous dry deposition in regional-scale numerical models, Atmos. Environ., 23, 1293-1304, doi:10.1016/0004-6981(89)90153-4, 1989.
Wesely, M. and Hicks, B.: A review of the current status of knowledge on dry deposition, Atmos. Environ., 34, 2261-2282, doi:10.1016/S1352-2310(99)00467-7, 2000.

WHO: Ambient (outdoor) air quality and health, available at: http:// www.who.int/mediacentre/factsheets/fs313/en/ (last access: June 2015), 2014.

Wild, O., Zhu, X., and Prather, M. J.: Fast-J: Accurate Simulation of In- and Below-Cloud Photolysis in Tropospheric Chemical Models, J. Atmos. Chem., 37, 245-282, doi:10.1023/A:1006415919030, 2000.

Wotawa, G., Novelli, P. C., Trainer, M., and Granier, C.: Interannual variability of summertime $\mathrm{CO}$ concentrations in the Northern Hemisphere explained by boreal forest fires in North America and Russia, Geophys. Res. Lett., 28, 4575-4578, doi:10.1029/2001GL013686, 2001.

Yarwood, G., Rao, S., Yocke, M., and Whitten, G.: Updates to the Carbon Bond Chemical Mechanism: CB05, Final Report to the US EPA, RT-0400675, available at: http://www.camx.com/publ/ pdfs/CB05_Final_Report_120805.pdf (last access: April 2014), 2005.

Young, P. J., Archibald, A. T., Bowman, K. W., Lamarque, J.-F., Naik, V., Stevenson, D. S., Tilmes, S., Voulgarakis, A., Wild, O., Bergmann, D., Cameron-Smith, P., Cionni, I., Collins, W. J., Dalsøren, S. B., Doherty, R. M., Eyring, V., Faluvegi, G., Horowitz, L. W., Josse, B., Lee, Y. H., MacKenzie, I. A., Nagashima, T., Plummer, D. A., Righi, M., Rumbold, S. T., Skeie, R. B., Shindell, D. T., Strode, S. A., Sudo, K., Szopa, S., and Zeng, G.: Preindustrial to end 21 st century projections of tropospheric ozone from the Atmospheric Chemistry and Climate Model Intercomparison Project (ACCMIP), Atmos. Chem. Phys., 13, 20632090, doi:10.5194/acp-13-2063-2013, 2013.

Zhang, Y.: Online-coupled meteorology and chemistry models: history, current status, and outlook, Atmos. Chem. Phys., 8, 28952932, doi:10.5194/acp-8-2895-2008, 2008.

Zilitinkevich, S.: Bulk characteristics of turbulence in the atmospheric planetary boundary layer, Tr. GGO, 167, 49-52, 1965. 